INTERNATIONAL MONETARY FUND

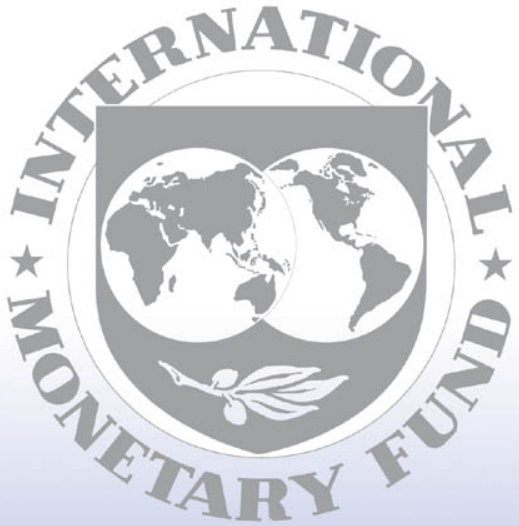

Staff

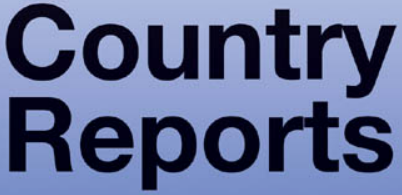




\section{Spain: 2004 Article IV Consultation-Staff Report; Public Information Notice on the Executive Board Discussion; and Statement by the Executive Director for Spain}

Under Article IV of the IMF's Articles of Agreement, the IMF holds bilateral discussions with members, usually every year. In the context of the 2004 Article IV consultation with Spain, the following documents have been released and are included in this package:

- the staff report for the 2004 Article IV consultation, prepared by a staff team of the IMF, following discussions that ended on November 8, 2004, with the officials of Spain on economic developments and policies. Based on information available at the time of these discussions, the staff report was completed on January 19, 2005. The views expressed in the staff report are those of the staff team and do not necessarily reflect the views of the Executive Board of the IMF.

- a Public Information Notice (PIN) summarizing the views of the Executive Board as expressed during its February 9, 2005 discussion of the staff report that concluded the Article IV consultation.

- $\quad$ a statement by the Executive Director for Spain.

The documents listed below have been or will be separately released.

Selected Issues Paper

Report on the Observance of Standards and Codes-Fiscal Transparency Module

The policy of publication of staff reports and other documents allows for the deletion of market-sensitive information.

To assist the IMF in evaluating the publication policy, reader comments are invited and may be sent by e-mail to publicationpolicy@imf.org.

Copies of this report are available to the public from

International Monetary Fund $\bullet$ Publication Services

$70019^{\text {th }}$ Street, N.W. $\bullet$ Washington, D.C. 20431

Telephone: (202) 623-7430 • Telefax: (202) 623-7201

E-mail: publications@imf.org•Internet: http://www.imf.org

Price: $\$ 15.00$ a copy

International Monetary Fund

Washington, D.C. 
INTERNATIONAL MONETARY FUND

SPAIN

\section{Staff Report for the 2004 Article IV Consultation}

Prepared by the Staff Representatives for the 2004 Consultation with Spain

Approved by Michael Deppler and G. Russell Kincaid

January 19, 2005

- Consultation discussions were held in Madrid during October 27-November 8, 2004. The staff team comprised Messrs. Leipold (head), Hoffmaister, Catalán, and Guajardo (all EUR), and Messrs. Spilimbergo (FAD) and Vázquez (MFD). Mr. Carstens, Deputy Managing Director, joined the mission for the final meeting. Mr. Moreno (OED) also participated in the meetings. The team met with Vice-Prime Minister and Minister of Economy Solbes, Bank of Spain Governor Caruana, other senior officials, and representatives of financial institutions, the employers' association, labor unions, and major political parties.

- Following elections in March 2004, a new government, led by the Socialist Party, took office. Its majority is dependent on various small left-wing and regional parties.

- Spain maintains an exchange system free of restrictions on payments and transfers for current international transactions, except for those maintained solely for the preservation of national or international security, and notified to the Fund under Decision No. 144(52/51); Spain has accepted the obligations of Article VIII, Sections 2, 3, and 4 (Appendix I).

- The authorities held a press conference on the mission's concluding statement (http://www.imf.org/external/np/ms/2004/110804.htm) and indicated their intention to publish this staff report. 


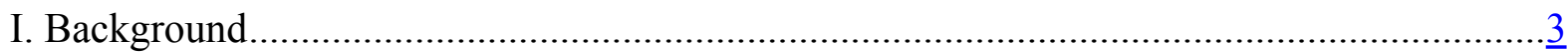

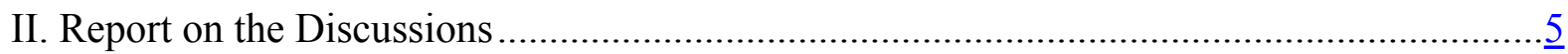

A. Cyclical Outlook and Risks .........................................................................

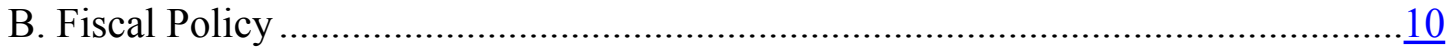

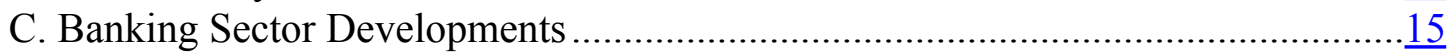

D. Labor and Product Markets..............................................................................

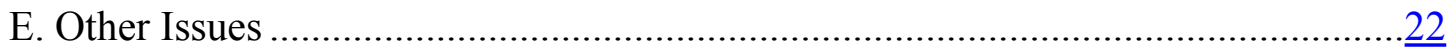

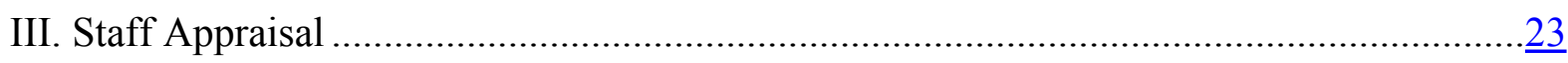

Boxes

1. Policy Recommendations and Implementation ……….....................................................

2. House Prices Overvaluation and Impact on Consumption ................................................ $\underline{8}$

Tables

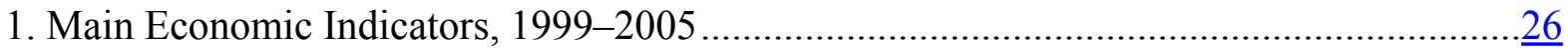

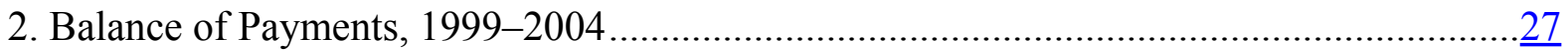

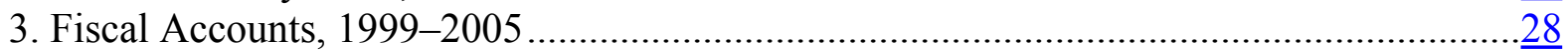

4. Public Sector Debt Sustainability Framework, 1997-2050 …………...............................

5. Updated Stability Program, 2003-08 ........................................................................

6. Indicators of External and Financial Vulnerability, 1999-2004 _........................................

Figures

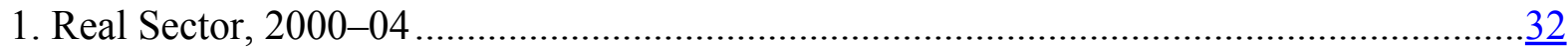

2. Headline and Core Inflation, 1997-2004 ………........................................................

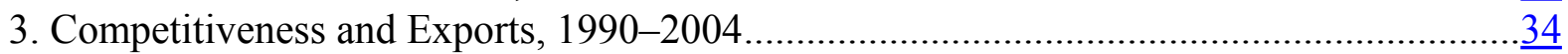

4. Demographic Shock and Health Spending ....................................................................

5. Convergence, and Labor Productivity and Utilization, 1970-2003 ………......................

Appendices

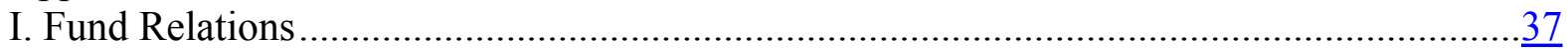

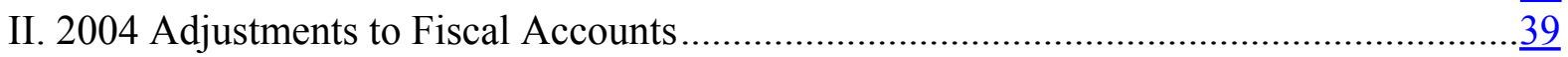

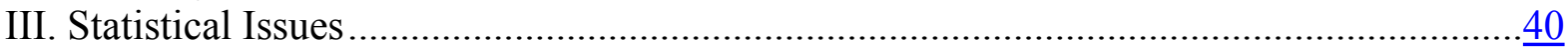




\section{BACKGROUND}

\section{The Spanish economy has weathered the EU slowdown well, thanks to the}

\section{strength of domestic}

demand (Table 1). The

economy was not

appreciably affected by

the terrorist attacks of

March 2004, and GDP

growth proceeded at a

steady pace of

2.6 percent in 2004 (the

staff-and now also

official-projection for
Selected Economic Indicators, 2002-04

(Real growth rates in percent, unless otherwise noted)

\begin{tabular}{|c|c|c|c|c|c|c|c|c|}
\hline & \multicolumn{2}{|c|}{2002} & \multicolumn{2}{|c|}{2003} & \multicolumn{2}{|c|}{$2004 \mathrm{H1}$} & \multicolumn{2}{|c|}{2004 Q3 } \\
\hline & Spain & Euro area & Spain & $\overline{\text { Euro area }}$ & Spain & Euro area & Spain & $\overline{\text { Euro area }}$ \\
\hline Real GDP & 2.2 & 0.9 & 2.5 & 0.5 & 2.6 & 1.7 & 2.6 & 1.8 \\
\hline Output gap 1/ & -0.3 & -0.3 & -0.8 & -1.7 & $\ldots$ & $\ldots$ & $\ldots$ & $\ldots$ \\
\hline Final domestic demand & 2.9 & 0.3 & 3.3 & 0.9 & 3.9 & 1.2 & 4.6 & 1.3 \\
\hline Net exports 2/ & -0.6 & 0.6 & -0.8 & -0.4 & -1.3 & 0.6 & -2.0 & 0.5 \\
\hline Harmonized inflation & 3.6 & 2.3 & 3.1 & 2.1 & 2.7 & 2.0 & 3.3 & 2.2 \\
\hline Employment & 2.0 & 0.5 & 2.7 & 0.2 & 3.0 & 0.3 & 2.5 & 0.4 \\
\hline
\end{tabular}

Sources: World Economic Outlook and Fund staff estimates.

1/ In percent of potential GDP.

2/ Contribution to growth.

the year as a whole), sustained in

particular by private consumption and construction (Figure 1). The pattern of growth has, however, become increasingly unbalanced: while the differential of final domestic demand growth over the euro area has remained large (over 3 percentage points in the third quarter of 2004), net exports have been an increasing source of drag (deducting 2 percentage points from GDP growth in the same period),

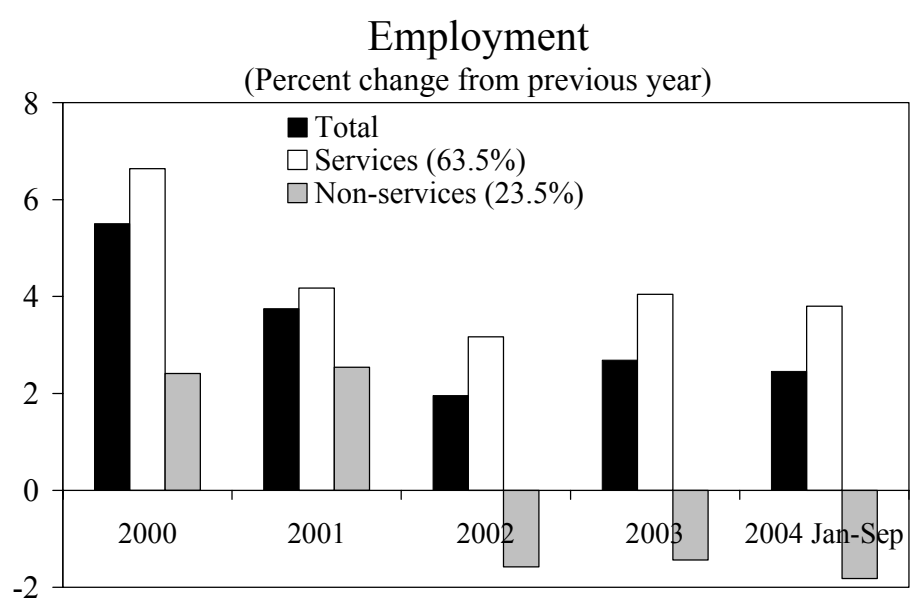
with comparatively weak export growth being swamped by the vigor of imports. Mirroring this pattern, employment remained buoyant in the service sectors, while nonservice sectorsmore exposed to international competition-registered continued losses.

\section{Inflation has been rising, with its continued margin over the euro area eroding} competitiveness (Figure 2).

Headline and core inflation Export Margins

(HICP) rose sharply in the course of 2004, reaching at end-year 3.3 percent and 2.9 percent, respectively, with the differential vis-à-vis the euro area remaining stubbornly around 1 percentage point (headline inflation). Inflation closely tracked movements in oil

(Year-on-year rate of change)

\begin{tabular}{lrrrrr}
\hline & 2002 & 2003 & \multicolumn{3}{c}{2004} \\
\cline { 4 - 6 } & & & Q1 & Q2 & Q3 \\
\hline Export margin & -3.0 & -1.4 & -1.2 & -0.4 & 0.0 \\
$\quad$ Exports deflator & 0.0 & -0.4 & -1.6 & -0.6 & 1.5 \\
$\quad$ Unit labor cost & 3.0 & 1.0 & -0.3 & -0.2 & 1.5 \\
Relative profitability of exports 1/ & -4.4 & -4.4 & -5.2 & -4.3 & -3.6 \\
$\quad$ Exports deflator & 0.0 & -0.4 & -1.6 & -0.6 & 1.5 \\
GDP deflator & 4.4 & 4.0 & 3.6 & 3.7 & 5.2 \\
\hline
\end{tabular}

Source: Bank of Spain.

1/ Assumes a common unit labor cost for the economy. 
4. Policy conditions have been accommodative. In particular, real interest rates have been in negative territory for some three years, spurring strong credit demand. The general government is estimatedexcluding one-off accounting adjustments amounting to 0.8 percent of $\mathrm{GDP}^{2}$ - to have recorded a slight surplus in 2004, implying a mildly stimulatory stance (Table 3 ). The strength of social security contributions has continued to ensure a comfortable social security surplus (slightly under 1 percent of GDP), more than offsetting the deficits recorded by the central and subnational governments.

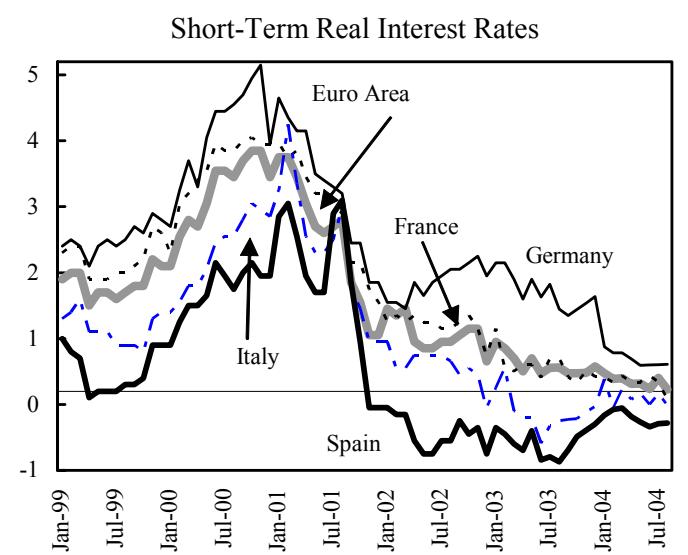

Sources: ECB; Datastream; and Fund staff calculations.

\section{REPORT ON THE DISCUSSIONS}

\section{Early in the tenure of the new Socialist-led government, the discussions-in} addition to reviewing policies to ward off short-term risks-focused on the government's announced priorities of fiscal stability, transparency, and productivity enhancement. In large part, the direction of policies in Spain has been in line with Fund advice (Box 1). Building on this record, the discussions sought to safeguard essential elements of achievements to date (notably the stability-orientation of fiscal policy), secure continued progress in initiatives underway (e.g., with respect to greater transparency), and assign higher priority to areas still largely on the drawing board (first and foremost, pension reform). Overall, the discussions were marked by a high degree of agreement, though policies in several areas remained to be defined and mixed signals, affecting policy cohesiveness, had emerged on some fronts.

\section{A. Cyclical Outlook and Risks}

6. The authorities were somewhat more sanguine than staff on the outlook. There was agreement that domestic demand (particularly consumption and construction) would remain robust and that net exports would continue exerting a drag on growth. Overall, however, the authorities expressed greater confidence in the economy's ability to weather the oil price rise and to gather steam going forward, and pointed in particular to evidence of a long-awaited pickup of investment in machinery and equipment. They noted that the negative contribution of the external sector thus also reflected the buoyancy of imports of capital

${ }^{2}$ The authorities - in the name of greater transparency - made a number of one-time adjustments to the general government accounts in 2004, corresponding primarily to the assumption of the debt of the railway operator, RENFE (see Appendix II). 


\section{Box 1. Spain: Policy Recommendations and Implementation}

Policy implementation in Spain has for several years been largely consistent with Fund policy advice, and based on a stability-oriented fiscal policy and structural reforms in labor and product markets. Fiscal policy has largely avoided the procyclical responses that the Fund saw as a potential risk in case of a rigid implementation of the Budgetary Stability Law. Improvements have been made in the strengthening of fiscal reporting and monitoring but these still fall short of what is needed, particularly at the subnational level.

A series of structural reforms have appreciably improved the workings of labor and product markets. Political and institutional constraints have, however, stood in the way of two long-advocated measures: comprehensive pension reform, key to long-term fiscal sustainability, and of the land supply and zoning process to improve its responsiveness and transparency. In addition, growing regional responsibilities in several areas have limited the central government's reach, inter alia complicating the implementation of competition policy.

goods. The discussions took place at a time of marked uncertainty regarding oil prices and exchange rates, and some of the differences in perspectives reflected different underlying assumptions. The authorities recently revised their 2005 growth projection downward, albeit only marginally, to 2.9 percent (from 3 percent in the 2005 budget) — still above staff (2.7 percent), but with both projections around estimates of potential growth.

7. Staff saw a greater risk of inflation persistence. The updated Stability Program (end-December) raised the official projection for inflation in 2005 to 3.1 percent (as measured by the private consumption deflator). Staff however remains less sanguine, as backward-looking wage indexation - affecting three-quarters of contracts - stands to exert pressure on wage costs. Given relatively high year-end inflation, a significant proportion of the revision clauses is likely to be triggered, risking second-round effects from the oil price increases. ${ }^{3}$ Furthermore, the pervasiveness of such wage indexation, along with the lack of effective competition in sheltered services sectors - where the income catch-up process is prompting relatively stronger demand pressures - risks contributing to the stubbornness of inflation.

\footnotetext{
${ }^{3}$ At the time of writing, there is also an ongoing debate on the indexation of the minimum wage.
} 

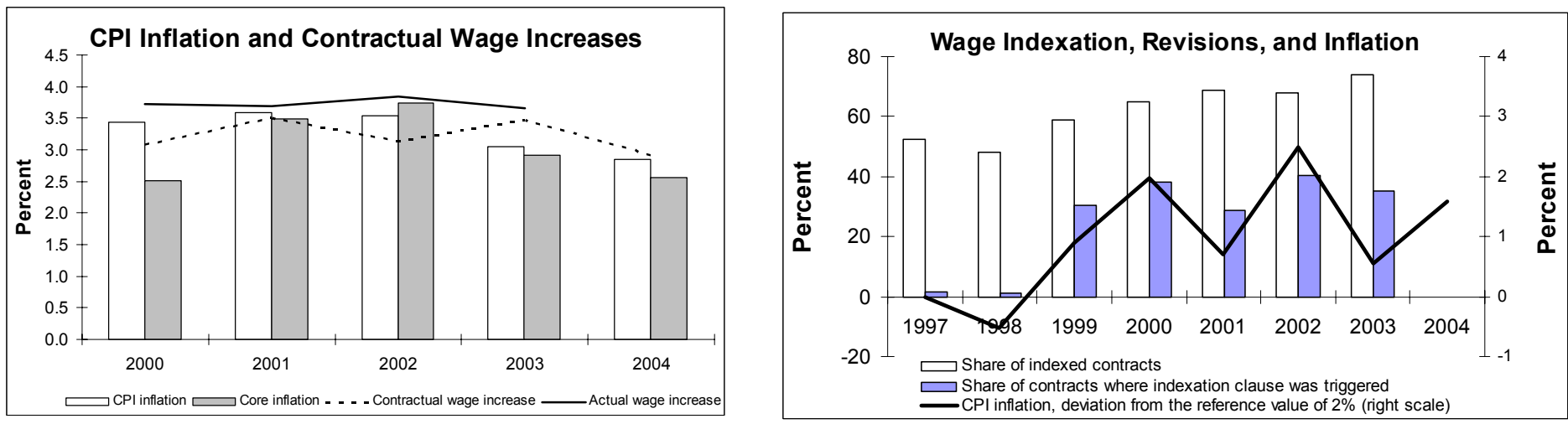

8. Oil price developments were seen to cloud prospects, particularly given Spain's relatively greater oil dependency. The authorities were nonetheless cautiously optimistic, both on future oil price movements and on their impact on the economy. They noted that the effect on growth (and inflation) of higher oil prices was being mitigated by the appreciation of the euro - which, they acknowledged, presented risks of its own. ${ }^{4}$ On the policy response to higher oil prices, they supported the ECOFIN's (and staff's) recommendation to allow domestic oil prices to adjust freely so as to shape incentives toward much-needed energy efficiency and conservation. The latter would be promoted also through appropriate energy policies (see 935). The authorities nonetheless introduced income tax rebates for the agriculture and fishing sectors

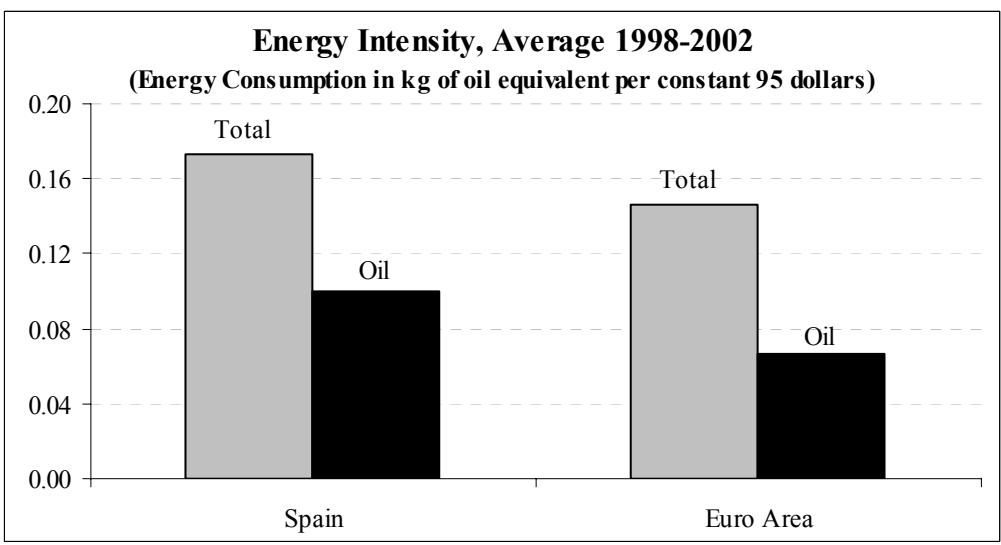
(which were seen as less able to pass on cost increases), while reassuring staff that the measures would be limited and temporary, and that similar calls from other sectors would be resisted.

9. The main domestic risk to the recovery is posed by the continued boom in house prices and the high level of household indebtedness. With house prices continuing their unrelenting rise, there was a greater readiness than in the past, both in private and official circles, to recognize that the prolonged boom had led to measurable overvaluation (Box 2). The authorities were inclined toward the lower range of available estimates, and saw the degree of overshooting as remaining within the bounds that would allow for an orderly

\footnotetext{
${ }^{4}$ The authorities estimated that a 10 percent increase in oil prices would reduce growth by about 0.1 percentage point in a year, at unchanged ECB interest rates; the impact would be twice as much if interest rates were to rise by 50 basis points.
} 


\section{Box 2. House Prices Overvaluation and Impact on Consumption}

The Bank of Spain uses two models to study the housing market. ${ }^{1}$ The first model posits that the observed real house price can be split into its long-run equilibrium value and a short-run deviation, with the equilibrium determined by real gross disposable income (per person older than 24), and the nominal interest rate on household mortgage loans. The second model posits that the observed price-rental ratio can be split analogously, with its equilibrium determined by the expected net present value of household consumption and (the growth in) house rents. The explanatory variables are derived from long-run projections of a reduced-form model (augmented by staff to include employment).

These models were re-estimated using data through 2004:Q3. The results suggest that house prices may be overvalued by 20 and 30 percent respectively in the most recent period (text figures $\mathrm{A}$ and $\mathrm{B}$ ) and remain within the range of historical deviations. It should be noted, however, that the second model could overstate the overvaluation to the extent that rental rates are subject to administrative controls, which could result in an undervaluation of rental prices. Also, the net present value of consumption might be underestimated due to structural changes in the economy.
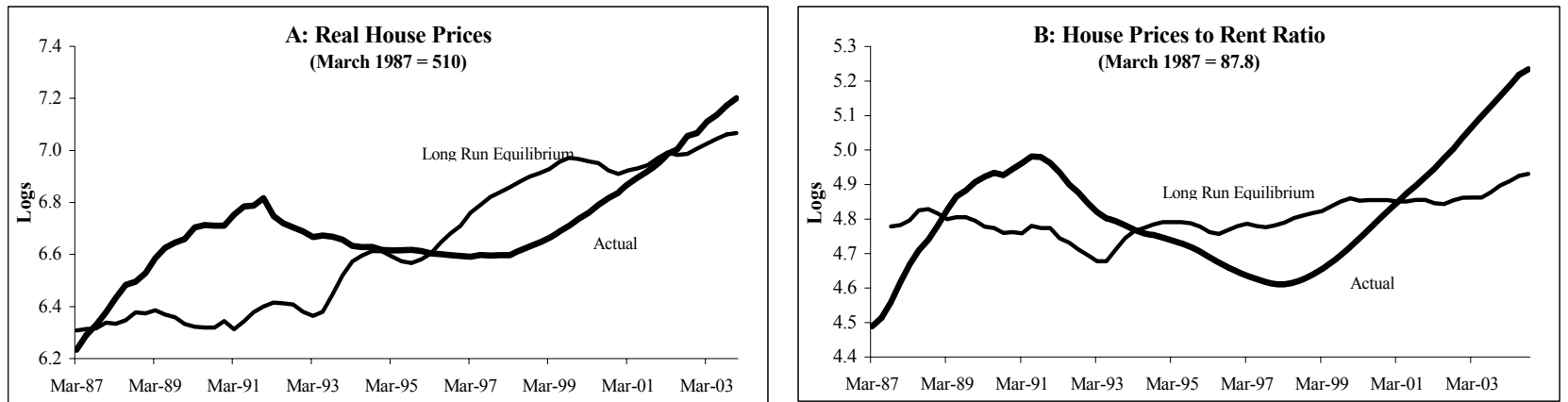

Assessing the potential impact on private consumption of a return to long-run equilibrium requires a macroeconomic model and specifying the adjustment scenario. Here, however, the impact is illustrated by using the consumption equation of the Bank of Spain's quarterly model ${ }^{2}$ — assuming an unchanged macroeconomic scenario — for two price correction paths. Figure $\mathrm{C}$ illustrates the cumulative impact from a correction path in real house prices similar to that experienced in 1992-96, when real house prices fell by about 20 percent (with more than half of the adjustment in the first year). This historical pattern of adjustment was applied to both models: the first illustrating a correction of 20 percent (12 percentage points in the first year, Model A) and the second depicting a correction of 30 percent (18 percentage points in the first year, Model B). The model suggests that consumption would decline by about $0.3(0.5)$ percent in two years in Model A (B).

Figure D depicts the cumulative effect of a more gradual decline in real house prices (1.0 and 1.5 percent real decline per quarter for 20 quarters in Model A and B respectively). In this case, consumption declines by about 0.1 (0.2) percent after two years in Model A (B).
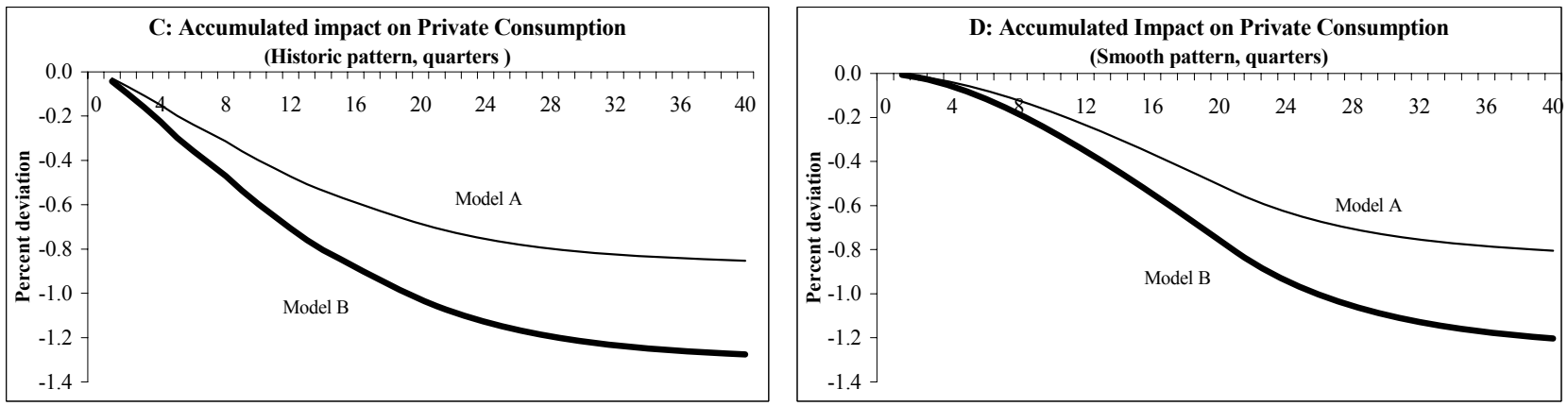

Note that these estimates do not account for macroeconomic effects working through income, employment, or the financial sector, and thus the declines are lower-bound estimates.

${ }^{1}$ See Bank of Spain Working Papers \#307, 2003 and \#304, 2003.

${ }^{2}$ See Bank of Spain Working Paper \#413, 2004. 
correction. They recalled the various fundamental factors driving house prices (historically low real interest rates, lengthened mortgage maturities, Spain's relatively later "baby boom," high immigration, and strong nonresident demand), ${ }^{5}$ and saw them as providing a reasonable degree of reassurance. They thus continued to hold the view that the situation was not yet alarming, but would become so if current trends were to persist. Staff noted that, with no signs of abatement in underlying trends, this view was becoming more tenuous. ${ }^{6}$

Furthermore, given Spain's high degree of home ownership ( 85 percent), real estate assets now account for more than 80 percent of household wealth, heightening the possible adverse effects on consumption from a price correction. Staff estimates (Box 2) put such effects at between 0.1 and 0.5 percent over two years, but these should be viewed as a lower bound, since they do not include the indirect macroeconomic effects that may work through income and employment - construction represents 12 percent of employment and 8 percent of GDP_nor possible financial sector strains. ${ }^{7}$

\section{The government's main response to the house price boom has consisted of measures to promote the underdeveloped rental market, along with increased investment in social housing. In July 2004, the government adopted a so-called "shock} plan" (Plan de Medidas Urgentes) to address the situation in the housing market. The plan focuses on measures to promote the rental market as a viable alternative to home ownership (mainly via subsidies for young renters and preferential credit lines to refurbish rental properties) and on an increase in the supply of social housing. It also sets up a new intermediation and information agency to promote rental activity (Agencia Pública de Alquiler) and a panel of experts charged with proposing reforms to the legal framework (whose limited protection to landlords was recognized to smother rental supply). While looking forward to the outcome of the latter work, staff saw the plan as not addressing fundamental problems in the housing market, notably: the distortions arising from arbitrary regulations governing developable land, and the unequal fiscal treatment favoring home ownership (at an annual budgetary cost of 0.4 percent of GDP). The authorities agreed on the importance of these issues but also stressed their complexity: the availability of developable land was closely linked to local authority financing, while established tax relief could not be easily changed or even (as suggested by staff) phased out without risking adverse sideeffects, including disruptions to construction activity (Spain's comparatively robust supply

\footnotetext{
${ }^{5}$ For details, see Country Report No. 04/89.
}

${ }^{6}$ In concluding the 2003 Consultation, the Executive Board had noted that "the boom in housing prices and rising household indebtedness - although driven by structural factors and not posing an imminent risk - cannot continue unabated without increasing the potential for an adverse fallout" (Public Information Notice No. 04/31, 4/2/2004).

${ }^{7}$ The impact is small also due to the low incidence of mortgage equity withdrawal, and the moderate sensitivity of private consumption, by EU standards, to nonfinancial private wealth. 
response was seen as a distinct strength to be preserved). They nonetheless saw possible room to address the tax issue in the broader context of personal income tax reform ( $\$ 14)$.

\section{B. Fiscal Policy}

\section{The near-term stance}

11. The 2005 budget is designed to reflect the new government's economic priorities of continued fiscal stability, productivity enhancement, and transparency. The budget targets a small general government surplus ( 0.1 percent of GDP), the same as that set in the previous government's Stability Program. On the revenue side, it contains no major tax initiatives, other than an adjustment of personal income tax brackets for inflation and small increases in taxes on alcohol and tobacco products. On the expenditure side, the ceiling on central government spending is set at a level that maintains a constant expenditure-to-GDP ratio, an objective the authorities viewed as key to securing fiscal discipline. However, they noted that the composition of spending had been tilted in favor of initiatives designed to enhance productivity (notably spending on R\&D, education, and public infrastructure). The budget also announces various initiatives to enhance competition and improve the regulatory framework in product markets.

\section{The budget documents include a number of innovations designed to further} enhance transparency of the central government accounts. A fiscal Report on the Observance of Standards and Codes (ROSC) mission in mid-2004 concluded that, thanks to steps taken over the last several years and recent initiatives, Spain now fully meets or exceeds the Fiscal Transparency Code's standards in many areas (see separate ROSC report, forthcoming). The Article IV mission welcomed, in particular, the inclusion in the 2005 budget of a reconciliation of budget and national accounts presentations and of information on potential risks emanating from certain public enterprises, as well as the intended close attention to be paid to contingent liabilities associated with private-public partnerships. ${ }^{8}$ Staff noted, however, that the announcement of a large multi-year investment project outside of the budget process (for national roadworks) ran against the grain of these initiatives.

13. The 2005 budget implies a mildly restrictive fiscal stance. The budget's target of a general government surplus of 0.1 percent of GDP is the same as the estimated outcome for 2004 (excluding one-off adjustments), making for a mild fiscal withdrawal. Despite slowerthan-budgeted real growth, staff saw higher inflation as likely to raise nominal GDP growth

\footnotetext{
${ }^{8}$ Spain is one of the ten countries selected for pilot case studies on public investment and fiscal policy following the Executive Board seminar of April 2004, on which the Board will be informed in the spring of 2005. The issue of strengthened monitoring and reporting of fiscal risks associated with public investment and public-private partnerships (PPPs) featured prominently in Country Report 04/89.
} 
even above the budget assumption. A larger-than-targeted surplus (in the order of 0.3 percent of GDP_-Table 3) was, in staff's view, thus both possible (thanks in particular to the continued strength of social security contributions, sustained by a planned further regularization of illegal immigrants) and desirable. The persistent inflation differential, the real estate asset boom, and the presence of overly easy monetary conditions for Spain all militated in favor a larger surplus. The authorities intended to let the stabilizers play toward a better outcome if that was forthcoming; staff encouraged a proactive approach in this direction.

\section{The authorities intend to revamp the personal income tax to broaden its base} and simplify the framework. Although no decisions had been made (and measures were likely only toward the end of the legislature, after a process of open public debate), consideration was being given to the possibility of a flat tax —including a moderately high exemption, and possibly a surcharge for higher income levels. The authorities estimated that, with the reduced tax rate under consideration, revenue neutrality would require a reassessment of tax deductions. Staff viewed the proposal with interest and looked forward to its further specification.

\section{Changes to the Budgetary Stability Law (BSL)}

\section{While recognizing the contribution of the Budgetary Stability Law-which} enshrines balanced budgets at the different levels of government — to promoting a culture of fiscal stability, the authorities intend to introduce a number of modifications. The authorities agreed on the importance of a disciplining fiscal framework for the maintenance of hard-earned fiscal stability. They highlighted the usefulness of several of the current framework's core elements, particularly the ceiling on central government spending, the contingency fund to deal with unforeseen circumstances, and the dedication of any social security surplus to the pension reserve fund. Nonetheless, they saw a need to modify the BSL with the promulgation of a new law (to be dubbed Budgetary Stability and Transparency Law) with a view to providing explicit scope for countercyclical action, increasing observance by the regions in a highly devolved system, and enhancing fiscal transparency. At the time of the mission, various working groups were examining alternative options; no final proposals have as yet been put forward.

16. A first intended modification is the reformulation of the BSL's annual "balanced budget" target as "balance-over-the-cycle," to avoid the risk of procyclical fiscal policy. Past Fund advice has called for a flexible implementation of the BSL to take due account of cyclical developments. ${ }^{1}$ The authorities were considering various ways to best achieve this goal, ranging from using pre-established formulae to compute the cyclical position and the

\footnotetext{
${ }^{9}$ For an empirical assessment of the procyclical nature of a rigid implementation of the BSL, see Country Report No. 03/41.
} 
fiscal stance, to a less structured system largely forgoing rules in favor of case-by-case judgments by a panel of experts. While mindful of the technical difficulties, staff favored a system governed by pre-specified, clear rules covering (a) the desirable medium-term target (which, due to the fiscal costs of aging, it saw as a small surplus - see $\$ 21$ ), and (b) the cyclical adjustment to this target, subjecting the resulting assessment of the cycle and the related structural fiscal position to public scrutiny. It pointed to Chile and Switzerland as providing potentially interesting country cases where fiscal objectives are expressed in structural terms and the methodology is clearly defined and publicly available. ${ }^{2}$ In this vein, it also encouraged setting up an independent, non-partisan agency to monitor budget assumptions and developments.

\section{The authorities also intend to enhance ownership to strengthen adherence to the} BSL by lower levels of government - essential given their large share of total spending. Following considerable expenditure decentralization, territorial entities now account for over 70 percent of public expenditure excluding social security. The authorities noted that, in the BSL's first year of implementation (2003), 11 of the 17 regions had recorded a deficit, rather than the mandated balanced budget (text table, next page). Although most of the deficits had been small, ${ }^{3}$ the authorities viewed the outcome with concern. Furthermore, several regions had challenged the constitutionality of

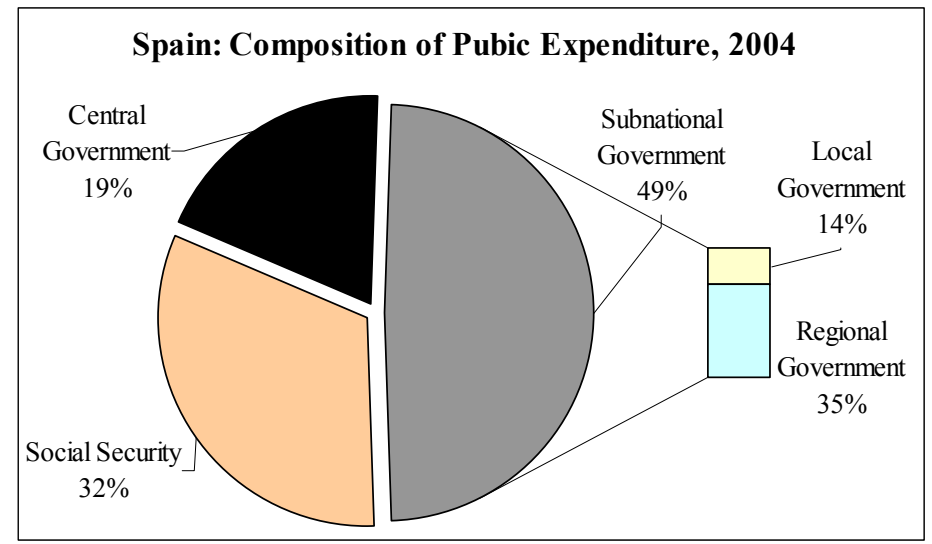
the BSL, perceived as impinging on their autonomy, and there was a risk of a legislative void if the appeals were accepted. The authorities thus saw a need for a greater degree of "buy-in" by the regions. Staff, while recognizing the importance of ownership, was concerned by the political economy forces at play in a situation in which the government depends on small regional parties for its majority, and cautioned that changes to the BSL be pondered carefully.

\footnotetext{
${ }^{10}$ Similarly, the U.S. Congressional Budget Office provides a detailed step-by-step derivation of the "standardized" and cyclically adjusted deficits on its website.

${ }^{11}$ Only the regions of Cataluña and Valencia had required adjustment plans. In monitoring the BSL, subnational fiscal balances are expressed as a percent of national GDP rounded to one decimal point $\left(2^{\text {nd }}\right.$ column of text table). Staff noted that this method favored smaller regions, and advocated measuring fiscal outturns in relation to regional GDP.
} 
Regional Fiscal Indicators

\begin{tabular}{|c|c|c|c|c|c|c|}
\hline & \multicolumn{2}{|c|}{$\begin{array}{c}\text { Fiscal Balance, } 2003 \\
\text { (Percent of GDP) }\end{array}$} & \multicolumn{2}{|c|}{$\begin{array}{c}\text { Public Debt, June } 2004 \\
\text { (Percent of GDP) }\end{array}$} & \multicolumn{2}{|c|}{$\begin{array}{c}\text { Credit Rating, October } 2004 \\
\text { (Long term) }\end{array}$} \\
\hline & Regional & National & Regional & National & Std. \& Poor's & Moody's \\
\hline Andalucía & 0.1 & 0.0 & 7.4 & 1.0 & AA-/Stable/-- & $\mathrm{Aa} 3$ \\
\hline Aragon & -0.1 & -0.0 & 4.7 & 0.1 & AA-/Stable/-- & $\ldots$ \\
\hline Asturias & 0.4 & 0.0 & 5.2 & 0.1 & $\ldots$ & $\ldots$ \\
\hline Canarias & -0.1 & -0.0 & 2.5 & 0.1 & AA/Stable/-- & $\ldots$ \\
\hline Cantabria & 0.2 & 0.0 & 3.1 & 0.0 & $\ldots$ & Aa3 \\
\hline Castilla y Leon 1/ & -0.0 & -0.0 & 2.8 & 0.2 & $\ldots$ & $\mathrm{Aa} 2$ \\
\hline Castilla-La Mancha & 0.0 & 0.0 & 4.4 & 0.1 & $\ldots$ & $\mathrm{Aa} 2$ \\
\hline Cataluña & -0.5 & -0.1 & 7.4 & 1.3 & AA/Stable/-- & Aa3 \\
\hline Extremadura 1/ & -0.0 & -0.0 & 6.0 & 0.1 & $\ldots$ & Aa3 \\
\hline Galicia & 0.2 & 0.0 & 8.2 & 0.4 & AA-/Stable/A-1+ & Aa3 \\
\hline Islas Baleares & -0.4 & 0.0 & 4.0 & 0.1 & $\mathrm{AA}+/$ Stable/-- & $\ldots$ \\
\hline La Rioja & -0.8 & 0.0 & 3.8 & 0.0 & $\ldots$ & $\ldots$ \\
\hline Madrid & 0.0 & 0.0 & 4.9 & 0.8 & AA/Stable/A-1+ & Aa3 \\
\hline Murcia & -0.2 & 0.0 & 3.4 & 0.1 & $\ldots$ & Aa3 \\
\hline Navarra 1/ & -0.0 & -0.0 & 5.1 & 0.1 & $\mathrm{AA}+/$ Stable/-- & $\ldots$ \\
\hline País Vasco & -0.1 & 0.0 & 2.3 & 0.1 & AA/Stable/-- & $\mathrm{Aa} 2$ \\
\hline Valencia & -1.3 & -0.1 & 11.1 & 1.1 & AA-/Stable/A-1+ & Aa3 \\
\hline Total & -0.2 & -0.2 & 6.0 & 6.0 & & \\
\hline
\end{tabular}

Source: Ministerio de Economia y Hacienda and Banco de España.

$1 /$ The fiscal balance is a small deficit, less than -0.05 , that is rounded up to zero.

\section{A key concern is how to effectively secure discipline at lower levels of}

government in a highly devolved political and institutional setting. There was agreement that, in such a setting, full use would need to be made of all available instruments (see Selected Issues paper). Among these, the authorities saw scope for increasing regional revenue-raising powers, strengthening the authorization process for subnational borrowings, and introducing an explicit no bail-out clause. Regional authorities could also consider improving budgetary processes - by including, for example, expenditure ceilings and contingency funds (as at the central government level) — was also viewed as holding promise.

\section{A related issue is that of the potential shortfall of transferred national revenues} relative to devolved non-discretionary expenditures, notably on education and health. National officials were unconvinced that any of the mandates were "unfunded." A possible exception was health, whose financing the government has undertaken to review in the course of 2005. A separate issue is the cyclicality of transferred revenues (which are based on revenue-sharing of national taxes, and thus related to actual GDP) in the face of the relative rigidity of expenditure on education and health. The authorities did not view this as a pressing matter, noting that — with a total share of such expenditures ranging between 60 and 70 percent of regional budgets and with scope for efficiency gains - there was a margin for regions to adjust under most plausible scenarios. They also emphasized that the transfer system was designed to strengthen the incentives toward greater fiscal discipline, and were keen not to undercut those efforts. While supporting these objectives, staff noted that, in any revision of the BSL, it would be important to ensure that the framework was cyclically robust. To this end, consideration might be given to making the transfers to the regions 
proportional to trend (or potential) rather than actual GDP. This would serve to limit cyclical swings in regional revenues and hence spending, thus reducing the scope for regional borrowing or procyclical policies, and help underpin the feature of the present system whereby regions should always aim to achieve budget balance. ${ }^{12}$ To the extent that - as appears to be the case in some of the proposals under study-regions would no longer be held to a "zero" budget balance, staff saw merit in the build-up of regional stabilization reserves ("rainy day funds") to provide savings for unexpected revenue shortfalls.

\section{Dealing with the fiscal consequences of aging}

20. Although the fiscal costs of aging are generally recognized, the focus has so far been mainly on the build-up of the pension reserve fund, with substantive action on pension reform continuing to be postponed. The sharp declines in fertility rates and increases in life expectancy are driving the demographic transition to an older Spanish population (Figure 4). The fiscal impact of aging, though setting in comparatively later than in other EU countries (after 2020), is considerable, amounting to some 6 percent of GDP by 2050, excluding healthcare. ${ }^{13}$ If left unaddressed, this demographic shock would increase public debt sharply by 2050

(Table 4). ${ }^{14}$ The authorities saw the Pacto de Toledo - a tripartite agreement signed in 1997 and laying out general principles for pension reform - as an effective instrument

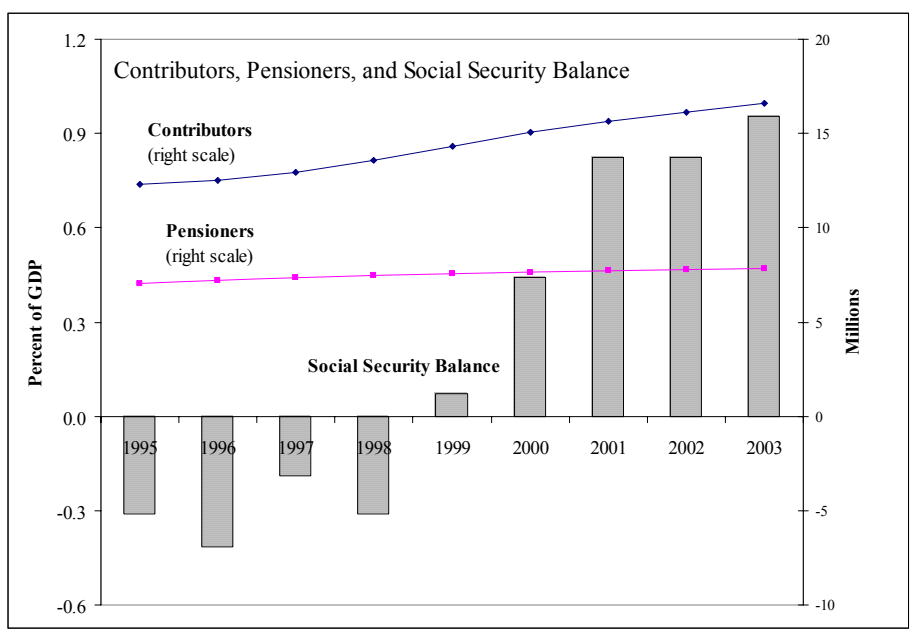
to build consensus on a reform agenda, but staff noted limited implementation of this agenda to date. The sense of urgency had also been muted by the large social security surpluses of

\footnotetext{
${ }^{12}$ Under such an arrangement, the anticyclical role would be essentially retained by the central government. The role of countercyclical fiscal policy at subnational level was studied extensively in the context of the U.S. in the 1970s when the fiscal role of states was becoming more relevant. The conclusion of this debate was that the countercyclical role should remain in the hands of the central authorities (see inter alia Wallace Oates, Fiscal Federalism, 1972, and Selected Issues paper).

${ }^{13}$ Staff estimates; the authorities noted that official long-term estimates will be updated in the course of 2005, in the context of ongoing work by the EU's Economic Policy Committee.

14 The potential macroeconomic consequences for Spain are also estimated to be substantial, despite higher immigration flows, and are treated in a chapter of the Selected Issues paper.
} 
recent years, fueled by the sharp increase in the number of contributors since the late 1990s and its coincidence with a small cohort of pensioners. The authorities confirmed their intention to continue to devote such surpluses to the pension reserve fund, which is set to approach 3 percent of GDP in 2005 (equivalent to some four months of benefits), resisting pressures for increased social spending and/or a generalized reduction of social security contributions.

\section{While welcoming the build-up of the reserve fund, staff pressed that} comprehensive pension reform be moved up on the policy agenda. Spain's demographic profile implies a peak in the dependency ratio in about 40 years with a subsequent reduction - at however a still relatively high level. In these circumstances, it appears reasonable to "pre-fund" the transitory impact through fiscal adjustment and to implement pension reform to ensure the longer-run sustainability of social security. Staff thus saw fiscal adjustment as a complement to, and not a substitute for, pension reform. On the first count, staff advised setting a moderate structural fiscal surplus as Spain's medium- to long-term fiscal target; the Stability Program updated in late December 2004 indeed envisages a gradually rising surplus, to slightly above the previous program's target for 2007 (to 0.4 percent of GDP) and extending the same to 2008 (Table 5). On the second count, staff encouraged the authorities to move ahead with reforms of the pension system that would increase the effective retirement age (primarily by changing the provisions governing early retirement) and further align contributions and benefits (by extending the base period used to compute pensions to life-long earnings). The authorities noted that, following the raising of this period from 8 to 15 years in 1997, its further lengthening was controversial; gradually raising the minimum contribution period was seen as likely to be a politically more acceptable route. There was recognition that aging, along with other factors (including immigration), would place pressures also on healthcare spending - as already apparent at the subnational level, where regions with an above-average share of the elderly face aboveaverage health costs (Figure 4). The authorities saw as immediate priorities addressing some particularly costly aspects of the pension and healthcare systems (notably surviving spouses' pensions, and abuses of disability pensions and extended sick leave). They also favored crafting a social pact on healthcare reform, along the lines of the Pacto de Toledo, as part of the upcoming review of the system's financing.

\section{Banking Sector Developments}

\section{The banking system continues to display a strong financial position, helped by} the favorable macroeconomic environment and the rebound of economic activity in Latin America. The authorities noted that the quality of bank assets had improved from already strong levels, with non-performing loans (NPLs) falling to a record low of 0.6 percent of gross loans, and provisioning surpassing 250 percent of NPLs. Although capitalization ratios have been eroded somewhat by the increase in risk-weighted assets as credit portfolios expanded, the Basel ratio remains above 12 percent (Table 6). In recent years, the strong expansion of credit has surpassed the growth of deposits, inducing banks to search for alternative sources of financing, including cross-border interbank credit, asset 
securitization, and asset-backed securities such as mortgage certificates. The average cost of banks' funds has consequently risen, compressing intermediation margins, affected also by declining interest rates and strong competition. The authorities noted that banks have however managed to shelter the bottom-line with strong retail activity, commission revenues, and cost containment. $^{15}$

\section{Banking risks associated with the housing market, although intensifying, were} viewed as remaining low. The strong expansion of mortgage lending has increased the exposure of the banking system to credit risk and/or a sudden correction in house prices. The authorities nonetheless saw these risks as remaining contained. Banks were seen to be largely shielded from sudden changes in house prices, as loan-to-value ratios are typically 80 percent (and far less on average since a large share of mortgages were issued when house prices were considerably lower). The authorities' assessment was that households could endure interest

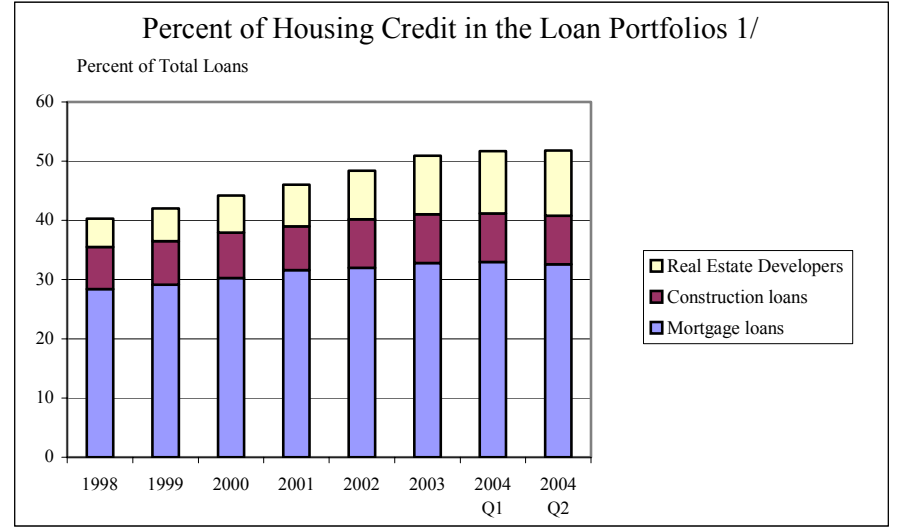

Source: Bank of Spain. Staff calculations.

1/ Excludes securitized (off-balance sheet) loans rate hikes of up to 300 basis points before experiencing loan repayment difficulties-an increase they viewed as unlikely in current circumstances. Bank provisioning (in excess of $€ 20$ billion) was seen to offer a reassuring additional cushion.

\section{The continued growth of mortgage credit-almost exclusively at variable} rates-was nonetheless viewed with concern. This was particularly the case with respect to credit to real estate developers, who in the past had faced difficulties when the real estate market had cooled off. The Bank of Spain has issued repeated calls for prudence, but felt

${ }^{15}$ The conduct of a Financial Sector Assessment Program (FSAP) in 2005 will provide a fuller analysis of the banking sector. 
that, beyond such moral suasion, there was little that could be done directly to rein in the expansion of credit. Prudential controls were seen to be operating adequately, and the authorities did not see a role for a tightening of such controls for cyclical credit management purposes. They put the emphasis rather on continued vigilance to ensure that credit institutions had in place effective credit approval and monitoring processes, which was viewed to be generally the case. More broadly, the authorities were intent on ensuring that the system could offer a wide variety of mortgage and financial products to facilitate the response to a prospective rise in interest rates, including through promoting greater use of fixed rates.

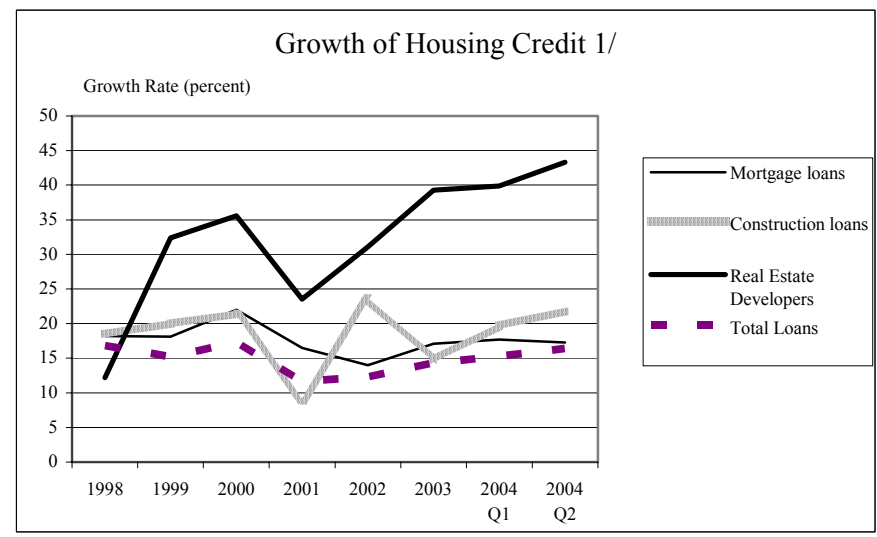

Source: Bank of Spain. Staff calculations.

1/ Excludes securitized (off-balance sheet) loans

\section{The governance of the savings banks (cajas) is being strengthened by the} ongoing implementation of new legislation. This legislation, approved in 2003, greatly reduced the presence and role of political appointees in the cajas' governing organs. It also strengthened the cajas' governance through the mandatory creation of Investment and Compensation Committees, which are entrusted with the approval of, respectively, new strategic investments and remuneration policies and their disclosure. Furthermore, beginning in 2004, the cajas — as well as all companies issuing publicly traded instruments - are required to publish an annual report on corporate governance. Staff welcomed these developments, stressing the need to remain vigilant, given a continued proclivity of political parties to attempt to influence cajas' decisions when important local issues are at stake.

\section{The authorities are well-advanced in defining new accounting and reporting} norms for deposit-taking institutions. The Bank of Spain had issued a draft circular, for public comment, revising accounting norms with a view to adoption of the International Financial Reporting Standards (IFRS) as from 2005. The circular provides new regulations governing asset classification and provisioning, risk measurement, reporting standards, and rules for consolidating financial conglomerates. On provisioning, although the circular envisages merging generic and "statistical" provisioning, the authorities emphasized that the countercyclical feature of the system — which they valued-would remain. ${ }^{1}$ The adjustment also imply some relaxation of provisioning parameters and tightening of classification rules.

\footnotetext{
${ }^{16}$ Statistical provisioning was introduced by the Bank of Spain in June 2000. Such provisioning is designed to cover expected losses on the basis of long-run experience over the cycle and, therefore, to mitigate the cyclical impact of specific provisions on banks' profit and loss accounts.
} 
Although the net effect on the level of provisions will depend on the specific characteristics of individual bank portfolios, the authorities expected some initial freeing up of resources for the system as a whole. In response to staff queries on whether this was timely, the authorities noted that the amounts involved were of a magnitude unlikely to have a macroeconomic effect, and that the timing was at all events dictated by the required adoption of International Financial Reporting Standards (IFRS) in 2005.

\section{Labor and Product Markets}

27. The new government places

particular emphasis on raising productivity, notably by enhancing competition in product markets. Despite data shortcomings, Spain's productivity performance has been lackluster (Figure 5), lagging behind the European average. In contrast, labor utilization has evolved relatively well, though staff noted the scope for further improvement, as testified by a still high unemployment rate. The authorities noted the importance of advancing on both fronts, pointing to the Irish experience as illustrating the benefits of increases in both productivity and employment. In response to staff queries about the role of public policy in enhancing productivity, the authorities - while assigning importance to promoting $\mathrm{R} \& \mathrm{D}$ and innovation - concurred that the government's role was primarily that of creating an enabling environment.

\section{Labor markets}

\section{Significant progress has been} made in improving the functioning of the labor market since the late 1990s, thanks to a series of labor market reforms. This is evident even in some traditionally lagging areas, such as long-term unemployment and the employment rate among older workers. While these trends have moved Spain closer to the EU average, it continues to lag significantly behind key Lisbon Objectives.
Breaking Down Relative GDP Per Capita

\begin{tabular}{lrrrrr}
\hline & 1970 & 1980 & 1990 & 2000 & 2003 \\
\hline \multicolumn{5}{c}{ (Euro area $=100$ in each row) } \\
GDP per capita & 75.6 & 74.1 & 77.1 & 83.2 & 85.9 \\
Labor Productivity & 75.1 & 80.0 & 82.9 & 78.4 & 78.0 \\
Labor utilization & 100.7 & 92.6 & 93.0 & 106.1 & 110.1 \\
$\quad$ Employment rate & 95.4 & 83.4 & 85.5 & 89.8 & 92.0 \\
Average hours of work & 106.5 & 114.1 & 110.5 & 116.2 & 117.3 \\
Demographics & 99.1 & 97.4 & 98.4 & 101.7 & 102.0 \\
Memo Item: & \multicolumn{5}{c}{ (US = 100 in each row) } \\
Euro area productivity & 65.8 & 85.0 & 93.1 & 97.3 \\
\hline Source: AMECO and OECD database. & 92.1 \\
Note: GDP per capita corresponds to GDP at current market prices (PPP) over total \\
population; labor productivity to GDP at current market prices (PPP) over total hours of \\
work; labor utilization to total hours of work over total population; employment rate to \\
employment over working-age population; average hours of work to total hours of work \\
over employment and demographics to working-age population over total population.
\end{tabular}

Productivity and Employment

(Ireland vs. Spain, 1995-2003)

\begin{tabular}{lcc}
\hline & Ireland & Spain \\
\hline & (Accumulated rate of growth) \\
GDP & 60.9 & 26.1 \\
Employment & 33.6 & 20.3 \\
Labor productivity & 27.3 & 5.8 \\
\hline
\end{tabular}

Source: Oficina Económica del Presidente.

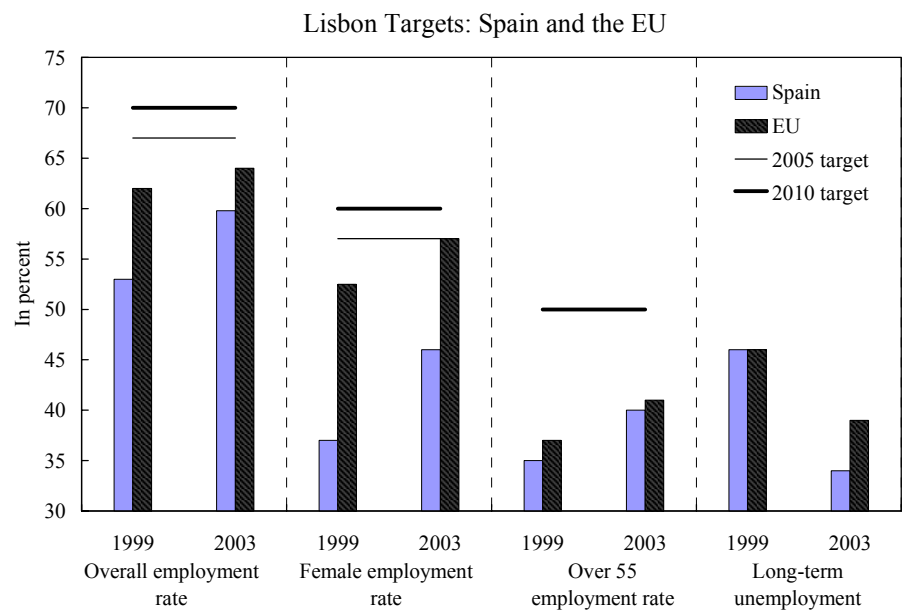




\section{Experience to date with the implementation of the 2002 reform of the} unemployment benefits system has been mixed. The reform was designed to promote active job search and greater geographical mobility, in the face of a very high regional dispersion of unemployment rates. Although formal observance of the reform's "return-towork" requirements appears high (e.g., all unemployment beneficiaries have signed so-called activity contracts), there remain doubts about its practical implementation-in terms of effective job search assistance and the application of sanctions-by the public employment agency. On the other hand, the reform has provided the possibility of side-stepping the protracted dismissal process, entailing an effective reduction in dismissal costs. This involves (text figure) declaring at the outset that a dismissal is unjustified, thereby avoiding the payment of "procedural" wages (salario de tramitación) during the prolonged settlement process. At any event, employers viewed recourse to court proceedings as largely ineffectual, as roughly three-quarters of all labor rulings favored the employee.

\section{The Spanish Dismissal Process}

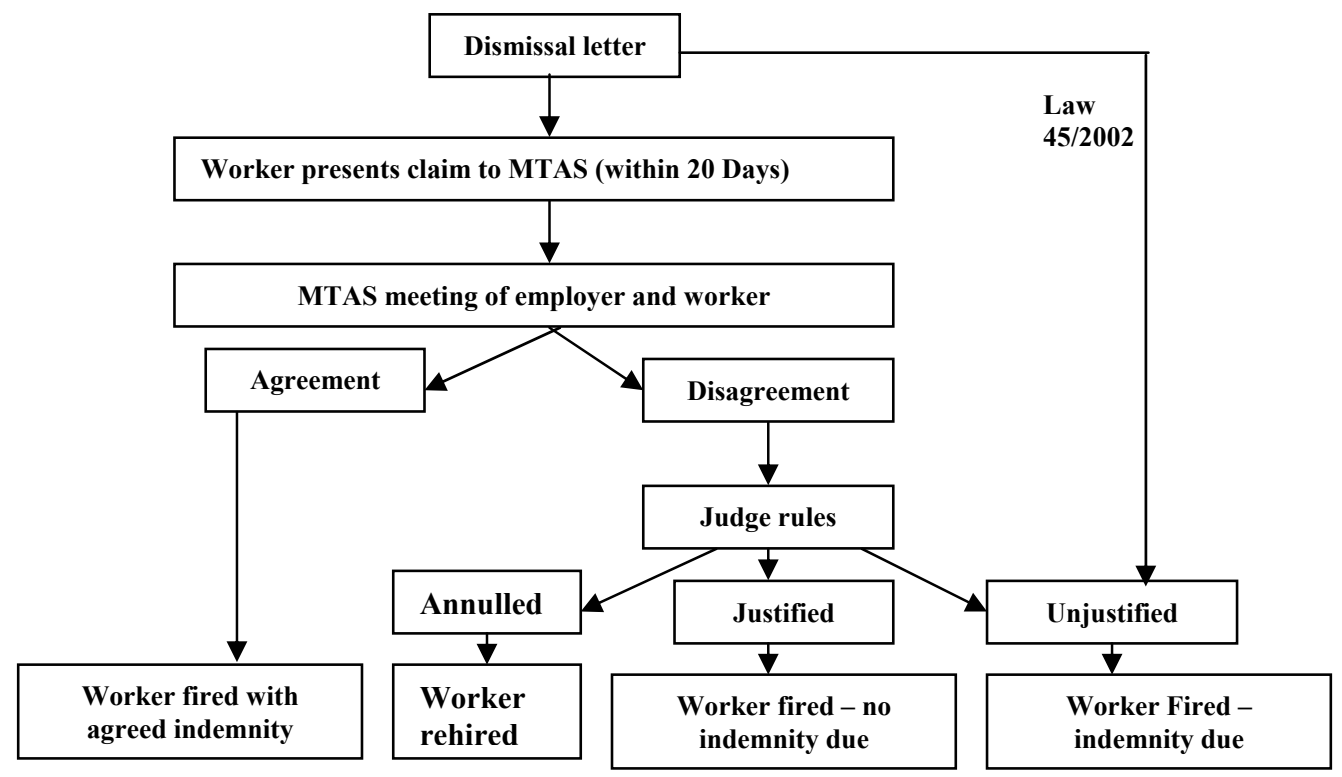

Note: The Bank of Spain estimates that in 2003 unjustified dismissals from Law 45/2002 were about twothirds of those that previously followed the MTAS route. Justified dismissals for economic reasons receive an indemnity of 20 days per year of service.

\section{Recent trends were seen to provide confidence in a gradual improvement in}

female employment rates. The authorities acknowledged that the root causes of Spain's low female employment rate - in comparison, for example, to the relatively higher rate of neighboring Portugal - were not well-understood, with some observers attributing it also to working hours that hamper balancing work and family commitments. They observed however that female labor market participation had grown steadily, following reforms that increased the flexibility of part-time work, established tax incentives for the creation of workplace childcare centers, and granted tax rebates for working mothers. The authorities 
noted marked changes in the pattern of female activity rates over the last few decades as providing confidence for the future: cohorts were increasingly participating in the labor market by joining later but remaining active longer (text figure). Among other factors, these changes were seen to reflect the increasing

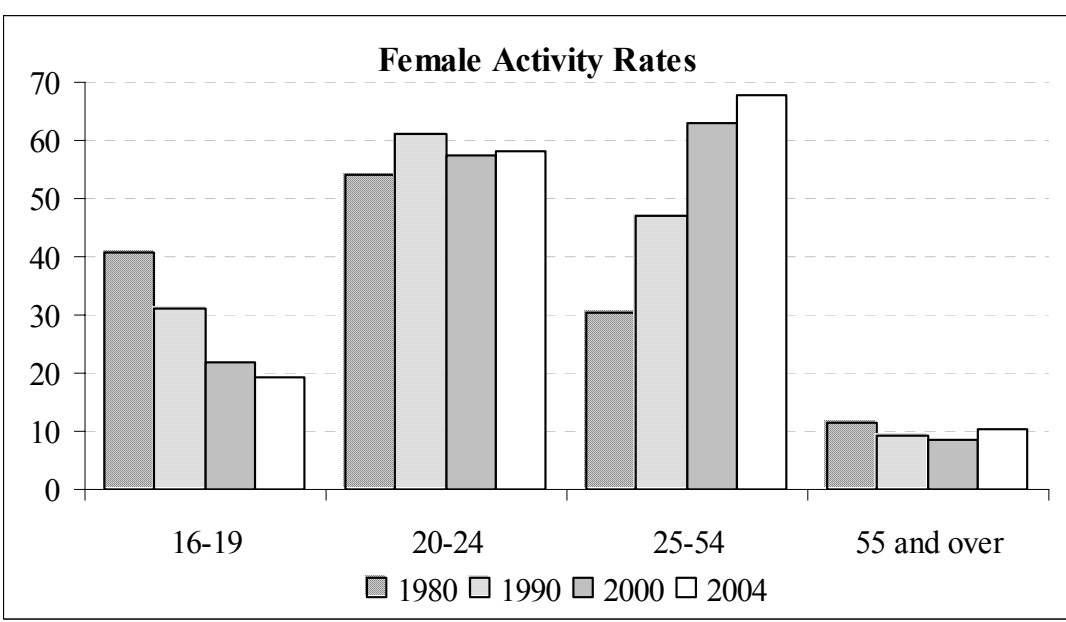
level of female education:

female activity rates among those holding university degrees are close to those of their male counterparts (only 3 percentage points lower), contrasting with the still large difference for workers with only a primary education (where the female activity rate is about 30 percentage points lower).

\section{Reducing the prevalence of fixed-term contracts to improve the quality of} employment is an official priority. Trade unions, in their meetings with staff, also saw this as a central plank of the ongoing social dialogue initiated by a tripartite declaration in July 2004. The authorities noted that the use of fixed-term contracts in the private sector had declined slightlyparticularly following the introduction in 1997 of openended contracts with lower dismissal costs and reduced social security contributions (so-called contratos de fomento). Still, Spain remained a clear outlier in the EU. ${ }^{17}$ This was seen to be partly attributable to the

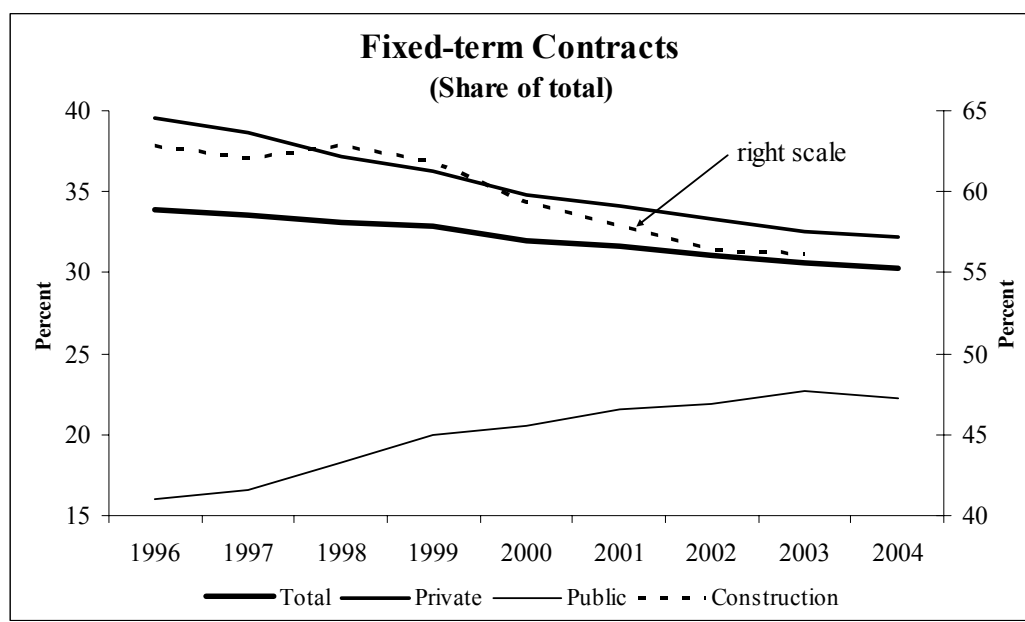
important role of the construction sector, where fixed-term contracts are widespread. Also, there had been a steady increase in the use of such contracts in the public sector, particularly at the municipal level. The authorities saw merit in continuing along the path of the 1997

${ }^{17}$ Fixed-term contracts account for about 30 percent of total employment, compared to a range of some 5-10 percent in most other EU countries (see Country Report No. 04/89). 
reform, extending the applicability of contratos de fomento to a wider range of sectors, while also rooting out abuse in the stringing of consecutive fixed-term contracts. The mission stressed the need to focus on the primary cause of the high recourse to fixed-term contracts, namely the considerably higher dismissal costs and rigidities of open-ended contracts. This wedge needed to be reduced by lowering the latter, rather than — as suggested in some quarters - rendering fixed-term contracts less attractive.

\section{The wage negotiating framework is also part of the ongoing social dialogue and} of potential importance to productivity developments. Staff reiterated the need for reform of a collective bargaining system that generates a high homogeneity of wage increases across sectors, skills, and regions, and is insufficiently attentive to relative productivity developments, dampens incentives to human capital accumulation, and discourages geographical mobility. Its institutional features also lead to an almost exclusive focus on the nominal wage award, at the expense of other key features that could help raise productivity (the flexibility of work organization, specific performance-related incentives, training, etc.). The authorities noted that the social dialogue agreement, while recognizing the importance of this issue, left it exclusively in the hands of the social partners.

\section{Immigration has become an increasingly important dimension of the Spanish} economy, particularly evident in the labor market. The government has approved a plan to regularize a large number of immigrants in the course of 2005. Although there was uncertainty regarding the number of illegal immigrants, rough estimates place the upper bound in the range of 1.2-1.3 million (about 3 percent of the population). ${ }^{18}$ The actual number likely to be regularized, however, was markedly less. The mission stressed that this heightened the importance of creating a flexible and adaptive labor market to ensure a smooth and efficient absorption of immigrants.

\section{Product markets}

34. While competition in a number of key product markets has advanced, obstacles to effective competition in retail distribution persist. Strengthened competition in key product markets has entailed notable price declines, and the full liberalization of the electricity and gas markets has advanced further. Going forward, the authorities intended to modernize the Competition Law, strengthen regulatory agencies, and liberalize professional services. At the same time, they recognized that competition in retail distribution - an area where subnational governments have jurisdiction and have erected a series of restrictionsremains wanting, accounting in some instances for a widening of retail margins. Lack of competition in this sector was viewed as all the more worrying in light of evidence that a large share of the productivity differential between the U.S. and EU countries lies in the

18 This estimate stemmed from the fact that there were some 2.4 million immigrants registered at the municipal level - a requisite to benefit from public education and health services - and only about 1.1 million were (legally) registered in the social security system. 
distributive trades. ${ }^{19}$ While the devolution of competencies in this area limited possible action by the central government, the authorities saw the EU Directive on Services in the Internal Market as providing an opportunity to address entry barriers throughout Spain. In this regard, staff was critical of the government's recent decision to lower minimum opening hours, noting that it reversed earlier efforts toward complete liberalization. The authorities recognized that the decision was a compromise in the face of legal recourse by certain regions, and stressed that the provision did not prevent regions from adopting more liberal regimes than the minimum indicated.

\section{E. Other Issues}

\section{The authorities noted progress in increasing energy efficiency and complying}

with the Kyoto Protocol. The goal is to increase the share of renewable sources of energy to 12 percent by 2012 (text table). Progress has been made in the generation of electrical power but less so in heating, and adjustments were under consideration to achieve the overall goal as envisaged. These efforts are complemented by an energy conservation strategy geared toward reducing projected energy use by 7.5 percent by 2012 . The authorities noted that the plan was consistent with the requirements of the Kyoto Protocol during 2005-07. It implies a small reduction in the emission of greenhouse gases for Spain ( 0.2 percent from 2002 levels), but was seen to demonstrate the country's resolve in meeting an international commitment to which they attributed importance.

Medium Term Energy Targets (Share of primary consumption)

\begin{tabular}{lcc}
\hline & 2004 & 2012 \\
\hline Coal & 12 & 8 \\
Oil & 51 & 48 \\
Natural gas & 18 & 23 \\
Nuclear & 11 & 9 \\
Renewable & 8 & 12 \\
\hline
\end{tabular}

Source: Dirección General de Política Energética y Minas.

36. The authorities saw a successful completion of the Doha trade round as key to sustained world economic growth, and in this context supported the 2003 reform of the Common Agricultural Policy (CAP). The reform will begin to be implemented in Spain as from 2006, while however maintaining the maximum permissible coupling of aids with production - an approach questioned by staff. Spain has furthermore expressed public reservations vis-à-vis reform initiatives affecting sugar and Mediterranean products. These would convert a large share of farm subsidies from production to income support, which the authorities expected to lead to a decline in sugar beet, cotton, and olive oil production, and possibly a significant change in the rural economy.

${ }^{19}$ Studies suggest that up to 50 to 75 percent of the productivity differential in market services between major EU countries and the U.S. is accounted by the distributive trades (wholesale and retail). This is attributed to the ability of large discount stores to use information technology intensively and to save costs from large-site operations and just-intime inventory management (see Adair Turner, "What's wrong with Europe's economy?," 2003). 
37. The authorities expressed their commitment to counter money laundering (AML) and the financing of terrorism (CFT). They reported on progress in implementing EU AML Directives, notably in the area of identifying individuals and activities, including the extension of reporting duties to new categories (including currency couriers and lotteries), and a strengthening of reporting requirements. The authorities stressed their strong commitment to CFT, given also Spain's unfortunate experience of terrorist attacks, but noted limits to such activity, since devastating acts of terrorism could be perpetrated with relatively limited funds: it was estimated, for example, that the Madrid attacks of March 2004 had cost under $€ 10,000$.

\section{Staff ApPraisal}

38. Spain's economic performance remains remarkably strong. Output growth and employment creation have been brisk, enterprises and banks have strengthened their balance sheets, and the fiscal accounts are in good health. The outlook is for continued economic growth in excess of the euro area average.

39. There are however clouds on the horizon, primarily in the form of inflation and housing market developments. The unbalanced nature of the recovery-largely consumption-led - and its related demand pressures in services sectors, where competition remains inadequate, is contributing to the stubbornness of inflation. Higher oil prices and backward-looking wage indexation are also set to prolong inflation and further erode competitiveness. At the same time, the unrelenting rise in house prices and household indebtedness - while driven by a number of fundamental factors - has raised the economy's vulnerability to adverse developments.

40. The government's priorities of fiscal stability, transparency, and productivity enhancement are well-placed. In various areas, these priorities now need to be translated into concrete measures to deal with both immediate and longer-term challenges and risks.

41. The persistent inflation differential and booming housing market, together with the presence of easy monetary conditions for Spain, argue for fiscal restraint. The 2005 budget target of a 0.1 percent of GDP surplus implies an only mildly restrictive stance. A better outcome is both possible and desirable, and should be pursued proactively by containing central government spending below the budget ceiling, safeguarding the contingency fund for truly exceptional circumstances, and fully saving the expected social security surplus. For their part, regional governments will need to adhere firmly to their commitment to balanced budgets.

42. Longer-run fiscal sustainability also requires pension reform. While moving to a larger-than-targeted fiscal surplus in 2005 and beyond would help toward dealing with the fiscal consequences of aging, fiscal restraint is not a substitute for comprehensive pension reform. The Pacto de Toledo has served to build consensus on a reform agenda, but progress has been disappointingly slow. If enacted promptly, reform measures could be phased in gradually, with relatively muted immediate effects, thus avoiding the need for more radical 
action as the demographic shock nears. For while this shock is further removed in time in Spain than in other EU countries, it stands to be considerable. Reforms will need to aim for a gradual increase in the effective retirement age and an improved alignment of benefits and contributions. Features of the system which perversely encourage early retirement also need to be corrected, with a potentially powerful growth-enhancing effect.

\section{Spain needs a strong budgetary framework, and the prime objective of changes} to the Budgetary Stability Law must be the promotion of greater overall fiscal discipline. Spain has been well served by a disciplining framework, with the BSL legally enshrining the objective of fiscal stability. Nonetheless, the authorities are seeking improvements by providing explicit room for countercyclical action, strengthening the framework's persuasive element, and increasing ownership and observance by the regions. These are complex issues, and changes to the BSL should be pondered carefully, shielded from political pressures, and guided by sound general principles. These establish that a model fiscal framework be well-defined and transparent: to this end, it should be governed by pre-specified, clear rules covering the desirable medium-term target, the methodology used to determine observance "over the cycle," and-importantly - the fiscal relations with subnational governments.

\section{Any fiscal framework needs to take account of Spain's constitutional reality in} which hard enforcement mechanisms for subnational governments are largely unavailable. In this setting, the arrangements should be cyclically robust over time, and designed with the objective of ensuring that the regions consistently aim at budget balance, avoiding a build-up in subnational debt. All admissible means to contain risks of fiscal laxity need to be drawn upon. Among such means, the regions could usefully arm themselves with the budgetary instruments that have proved their worth at the central government level, notably an expenditure ceiling and a contingency fund. There is also a role for increased regional revenue-raising powers, to enhance local accountability, and for a more effective use of borrowing authorizations. Independent agencies reporting their assessments of budgetary developments and trends to national and regional parliaments could also play a useful role in bolstering the fiscal framework's effectiveness.

45. Ultimately, however, enforcement will need to rely largely on dissuasive peer and public pressure, whose exercise requires the highest degree of fiscal transparency, as recommended by the fiscal ROSC. A rationale for decentralization is that proximity breeds greater efficiency and accountability, but this holds only if the public is adequately informed about the state of local finances. In this light, a critical ingredient - a sine qua non - of any change to the fiscal framework embodied in the BSL must be increased transparency of the subnational governments' fiscal accounts. This should include timely publication of data on regional budget execution and, more generally, the pursuit of a degree of transparency similar to that being commendably sought at the central government level.

46. Fundamental problems affecting the housing market remain to be addressed. A resolution of these problems will require bolder measures than those contained in the authorities' plan, and aim in particular at (i) phasing out the unequal fiscal treatment arising 
from generous tax relief that favors home ownership and weighs heavily on the budget; (ii) changing a legal framework that is prejudicial to rental activity; and (iii) reforming the regulations governing developable land that limit its supply. Until these key issues are dealt with resolutely, other measures will likely have only a palliative effect.

\section{In the labor market, earlier reforms are bearing fruit, but further action is} needed to approach the still distant Lisbon Objectives. The intense immigration to Spain, which has contributed to the strong growth performance of recent years, requires an adaptive labor market for its smooth and efficient absorption. The outcome of the ongoing social dialogue should be unequivocally in this direction. The response being sought to Spain's uncommonly high rate of temporary employment contracts should thus be guided by the principle of increasing labor market flexibility, with the primary avenue being a reduction in the rigidity and high dismissal costs of standard open-ended contracts. There also remains a need for changes to the collective wage bargaining system, with a greater attention to relative productivity and non-wage aspects of work organization that could contribute to the desired improvement in the economy's productivity performance.

48. In product markets, the emphasis on increased competition in various areas is well-placed. A continued sore point remains that of the various restrictions to effective competition in retail distribution imposed by the subnational authorities who have competence in the matter. Such barriers have costs for the regions themselves, in terms of their relative attractiveness for investors, consumer welfare, and economic performance. The opportunity provided by the EU Directive on Services in the Internal Market should be actively pursued to remove entry barriers throughout Spain.

49. Commercial banks and cajas are recording increasingly positive results, but the continued expansion of real estate-related lending has raised vulnerabilities. The Bank of Spain's ongoing vigilance in this area is well-placed. Also important are the steps to ensure that the system is in a position to flexibly offer financial products that could facilitate the response to a prospective rise in interest rates. In other areas, Spain is commendably well-advanced in defining new accounting rules for deposit-taking financial institutions, and the strengthening of governance in the cajas has proceeded, helping to increase the protection against unwarranted political interference. The planned conduct of a Financial Sector Assessment Program (FSAP) in 2005 is welcome.

50. Spain is encouraged to build on the increase in Official Development Assistance (ODA) in 2004 and move closer to the 0.7 percent of GNP benchmark. Spain's support for trade liberalization is welcome, and the authorities are encouraged to actively promote the completion of the Doha Round, including by supporting the flexibility needed on agricultural trade issues. Spain's data are adequate for effective surveillance, although the quality of productivity data and the frequency and timeliness of regional fiscal data need to be improved (Appendix III).

51. It is recommended that the next consultation be held on the standard 12-month cycle. 
Table 1. Spain: Main Economic Indicators, 1999-2005 1/

(In percent of GDP, unless otherwise indicated)

\begin{tabular}{|c|c|c|c|c|c|c|c|}
\hline & & & & & & Projec & \\
\hline & 1999 & 2000 & 2001 & 2002 & 2003 & 2004 & 2005 \\
\hline Demand and supply in constant prices & & & & & & & \\
\hline Gross domestic product & 4.2 & 4.4 & 2.8 & 2.2 & 2.5 & 2.6 & 2.7 \\
\hline Private consumption & 4.7 & 4.1 & 2.8 & 2.9 & 2.9 & 3.3 & 3.4 \\
\hline Public consumption & 4.2 & 5.6 & 3.5 & 4.1 & 3.9 & 4.2 & 3.7 \\
\hline Gross fixed investment & 8.8 & 5.7 & 3.0 & 1.7 & 3.2 & 4.4 & 4.9 \\
\hline Equipment investment & 8.6 & 5.2 & 0.4 & -2.6 & 1.7 & 4.5 & 5.5 \\
\hline Construction investment & 9.0 & 6.2 & 5.3 & 5.2 & 4.3 & 4.3 & 4.4 \\
\hline Stockbuilding (contribution to growth) & 0.1 & -0.1 & -0.1 & 0.0 & 0.1 & 0.2 & 0.1 \\
\hline Total domestic demand & 5.6 & 4.6 & 2.9 & 2.8 & 3.2 & 3.9 & 3.9 \\
\hline Net exports (contribution to growth) & -1.4 & -0.3 & -0.2 & -0.6 & -0.8 & -1.5 & -1.4 \\
\hline Exports of goods and services & 7.7 & 10.1 & 3.6 & 1.2 & 2.6 & 5.3 & 7.4 \\
\hline Imports of goods and services & 12.6 & 10.5 & 3.9 & 3.1 & 4.8 & 9.1 & 10.3 \\
\hline Potential output growth & 3.4 & 3.3 & 3.3 & 3.2 & 3.0 & 2.8 & 2.8 \\
\hline Output gap (percent of potential) & 0.0 & 1.1 & 0.6 & -0.3 & -0.8 & -1.0 & -1.2 \\
\hline Private credit growth $2 /$ & 15.4 & 17.2 & 11.8 & 12.3 & 14.2 & 16.2 & $\ldots$ \\
\hline Prices & & & & & & & \\
\hline GDP deflator & 2.7 & 3.4 & 4.2 & 4.5 & 4.0 & 3.8 & 4.0 \\
\hline HICP (average) & 2.2 & 3.5 & 2.8 & 3.6 & 3.1 & 3.0 & 3.5 \\
\hline Employment and wages & & & & & & & \\
\hline Unemployment rate (in percent) & 15.7 & 13.9 & 10.5 & 11.4 & 11.3 & 10.8 & 10.4 \\
\hline Unit labor cost in manufacturing (growth rate) & 1.2 & 2.3 & 4.1 & 3.0 & 1.0 & 1.4 & 2.7 \\
\hline Wage growth & 2.7 & 3.7 & 3.7 & 3.8 & 3.4 & 3.0 & $\ldots$ \\
\hline Employment growth & 5.5 & 5.5 & 3.7 & 2.0 & 2.7 & 2.5 & 2.3 \\
\hline Labor participation rate (in percent) 3/ & & & & & & & \\
\hline Total & 52.5 & 53.6 & 52.9 & 54.0 & 55.1 & $\ldots$ & $\ldots$ \\
\hline Male & 65.8 & 66.6 & 66.2 & 66.9 & 67.5 & $\ldots$ & $\ldots$ \\
\hline Female & 39.9 & 41.3 & 40.3 & 41.8 & 43.3 & $\ldots$ & $\ldots$ \\
\hline Personal sector & & & & & & & \\
\hline Household savings (percent of disposable income) & 11.2 & 10.8 & 10.3 & 10.6 & 10.7 & 11.0 & $\ldots$ \\
\hline Balance of payments (percent of GDP) & & & & & & & \\
\hline Trade balance & -5.1 & -6.2 & -5.6 & -5.0 & -5.1 & -6.1 & -6.8 \\
\hline Current account balance & -2.3 & -3.4 & -2.8 & -2.4 & -2.8 & -4.0 & -4.6 \\
\hline Official reserves excl. gold (US\$ billions) & 33.9 & 31.8 & 30.3 & 35.3 & 37.8 & 40.4 & $\ldots$ \\
\hline Nominal effective rate $(1990=100) 4 /$ & 74.7 & 71.9 & 72.3 & 74.2 & 76.8 & 76.8 & $\ldots$ \\
\hline Real effective rate $(1990=100) 4 /$ & 85.3 & 83.1 & 84.8 & 88.9 & 92.7 & 93.6 & $\ldots$ \\
\hline Public finance (percent of GDP) & & & & & & & \\
\hline General government balance & -1.2 & -0.9 & -0.4 & -0.1 & 0.4 & -0.8 & 0.3 \\
\hline Primary balance & 2.4 & 2.4 & 2.8 & 2.7 & 2.9 & 1.3 & 2.3 \\
\hline Structural balance $5 /$ & -1.0 & -1.3 & -0.8 & 0.3 & 1.0 & 0.7 & 1.1 \\
\hline Structural primary balance $5 /$ & 2.3 & 1.8 & 2.1 & 2.8 & 3.2 & 2.8 & 3.1 \\
\hline General government debt & 63.1 & 61.1 & 57.5 & 54.4 & 50.7 & 48.4 & 45.0 \\
\hline
\end{tabular}

Sources: IMF, World Economic Outlook and Information Notice System; and Fund staff estimates.

1/ Figures for 2004 and 2005 are Fund staff projections.

$2 /$ In 2004, the growth rate is for November (y-o-y).

3/ Based on national definition, i.e., the labor force is defined as people older than 16 .

4/ As of October 2004.

5/ Calculations exclude one-off adjustments amounting to 0.1 percent of GDP in 2000 (auction of mobile telephone licenses) and 0.8 percent of GDP in 2004 (mostly the assumption of debt of the railway operator, RENFE). 
Table 2. Spain: Balance of Payments, 1999-2004

\begin{tabular}{|c|c|c|c|c|c|c|}
\hline & 1999 & 2000 & 2001 & 2002 & 2003 & $2004 \mathrm{H} 1$ \\
\hline & \multicolumn{6}{|c|}{ (In billions of euros) } \\
\hline Current account balance & -13.1 & -21.0 & -18.3 & -16.9 & -20.8 & -15.8 \\
\hline Trade balance & -28.6 & -37.8 & -36.4 & -34.6 & -37.8 & -22.3 \\
\hline Exports of goods & 105.7 & 126.1 & 131.7 & 135.6 & 141.0 & 74.5 \\
\hline Imports of goods & 134.3 & 163.8 & 168.1 & 170.2 & 178.9 & 96.7 \\
\hline Balance of non-factor services & 21.5 & 24.2 & 27.1 & 26.6 & 27.3 & 10.4 \\
\hline Balance of factor income & -8.9 & -9.0 & -10.9 & -11.3 & -10.6 & -5.5 \\
\hline Balance of current transfers & 2.9 & 1.5 & 1.8 & 2.4 & 0.3 & 1.6 \\
\hline Balance of capital and financial account & 17.8 & 26.5 & 25.6 & 22.5 & 26.4 & 17.7 \\
\hline Foreign direct investment & -24.7 & -18.6 & -5.7 & 4.7 & 2.0 & 4.7 \\
\hline Portfolio & -1.4 & -1.4 & -19.8 & 5.2 & -45.3 & 19.7 \\
\hline Other investment & 16.2 & 38.0 & 43.7 & 8.4 & 47.5 & -15.4 \\
\hline Capital transfers & 6.7 & 5.2 & 5.9 & 7.9 & 8.6 & 4.3 \\
\hline Reserve assets & 21.0 & 3.3 & 1.6 & -3.6 & 13.6 & 4.4 \\
\hline \multirow[t]{2}{*}{ Errors and omissions } & -4.7 & -5.5 & -7.3 & -5.6 & -5.6 & -1.9 \\
\hline & \multicolumn{6}{|c|}{ (In percent of GDP) } \\
\hline Current account balance & -2.3 & -3.4 & -2.8 & -2.4 & -2.8 & -4.1 \\
\hline Trade balance & -5.1 & -6.2 & -5.6 & -5.0 & -5.1 & -5.7 \\
\hline Exports of goods & 18.7 & 20.6 & 20.1 & 19.4 & 18.9 & 19.1 \\
\hline Imports of goods & 23.8 & 26.8 & 25.7 & 24.4 & 24.0 & 24.8 \\
\hline Balance of non-factor services & 3.8 & 4.0 & 4.1 & 3.8 & 3.7 & 2.7 \\
\hline Balance of factor income & -1.6 & -1.5 & -1.7 & -1.6 & -1.4 & -1.4 \\
\hline Balance of current transfers & 0.5 & 0.3 & 0.3 & 0.3 & 0.0 & 0.4 \\
\hline Balance of capital and financial account & 9.5 & 5.6 & 1.6 & 2.8 & 3.5 & 3.2 \\
\hline Foreign direct investment & -4.4 & -3.0 & -0.9 & 0.7 & 0.3 & 1.2 \\
\hline Portfolio & -0.2 & -0.2 & -3.0 & 0.7 & -6.1 & 5.1 \\
\hline Other investment & 10.4 & 8.3 & 5.3 & 2.0 & 7.5 & 2.9 \\
\hline Reserve assets & 3.7 & 0.5 & 0.2 & -0.5 & 1.8 & 1.1 \\
\hline Errors and omissions & -0.8 & -0.9 & -1.1 & -0.8 & -0.7 & -0.5 \\
\hline
\end{tabular}

Sources: IMF, World Economic Outlook, and Fund staff projections. 
Table 3. Spain: Fiscal Accounts, 1999-2005

(In percent of GDP)

\begin{tabular}{|c|c|c|c|c|c|c|c|}
\hline & \multirow[b]{2}{*}{1999} & \multirow[b]{2}{*}{2000} & \multirow[b]{2}{*}{2001} & \multirow[b]{2}{*}{2002} & \multirow[b]{2}{*}{2003} & \multicolumn{2}{|c|}{ Projections } \\
\hline & & & & & & 2004 & 2005 \\
\hline Current revenues & 38.3 & 38.5 & 38.7 & 38.9 & 39.1 & 39.2 & 39.3 \\
\hline Indirect taxes & 11.7 & 11.7 & 11.4 & 11.6 & 11.9 & 12.0 & 11.9 \\
\hline Direct taxes & 10.2 & 10.5 & 10.5 & 10.9 & 10.6 & 10.6 & 10.8 \\
\hline Social security contributions & 13.1 & 13.3 & 13.6 & 13.5 & 13.7 & 13.7 & 14.3 \\
\hline Other current revenues & 3.3 & 2.9 & 3.2 & 2.9 & 2.9 & 2.9 & 2.3 \\
\hline Current expenditures & 35.4 & 35.2 & 34.8 & 34.7 & 34.6 & 35.1 & 34.8 \\
\hline Public consumption & 17.1 & 17.2 & 17.2 & 17.2 & 17.5 & 17.6 & 17.7 \\
\hline Current transfers & 12.4 & 12.3 & 12.2 & 12.3 & 12.2 & 12.5 & 12.5 \\
\hline Interest payments & 3.5 & 3.3 & 3.1 & 2.8 & 2.5 & 2.3 & 2.2 \\
\hline Other current expenditures & 1.2 & 1.2 & 1.2 & 1.3 & 1.3 & 1.5 & 1.4 \\
\hline Current balance & 2.9 & 3.3 & 3.9 & 4.2 & 4.4 & 4.1 & 4.5 \\
\hline Gross fixed capital formation & 3.5 & 3.1 & 3.3 & 3.5 & 3.5 & 3.6 & 3.7 \\
\hline Capital transfers and other & 1.3 & 1.4 & 1.4 & 1.4 & 1.3 & 2.1 & 1.3 \\
\hline Primary balance & 2.2 & 2.3 & 2.6 & 2.6 & 2.7 & 1.3 & 2.3 \\
\hline Overall balance & -1.2 & -0.8 & -0.3 & 0.1 & 0.4 & -0.8 & 0.3 \\
\hline Central government & -1.1 & -0.9 & -0.5 & -0.4 & -0.3 & -1.8 & -0.5 \\
\hline Territorial governments $2 /$ & -0.2 & -0.4 & -0.5 & -0.3 & -0.3 & 0.2 & -0.2 \\
\hline Social security & 0.1 & 0.4 & 0.8 & 0.8 & 1.0 & 0.8 & 1.0 \\
\hline Government debt & 63.1 & 61.3 & 57.8 & 54.4 & 50.7 & 48.4 & 45.0 \\
\hline \multicolumn{8}{|l|}{ Memorandum items: } \\
\hline Structural primary balance $1 /$ & 2.3 & 1.8 & 2.1 & 2.8 & 3.2 & 2.8 & 3.1 \\
\hline Structural balance 1/ & -1.0 & -1.3 & -0.8 & 0.3 & 1.0 & 0.7 & 1.1 \\
\hline Structural expenditure & 40.0 & 40.2 & 40.0 & 39.4 & 39.0 & 39.3 & 39.1 \\
\hline Structural revenue & 39.0 & 38.9 & 39.2 & 39.6 & 39.9 & 40.1 & 40.2 \\
\hline
\end{tabular}

Sources: Cuentas Financieras, Bank of Spain; Intervención General de la Administración del Estado; and Fund staff projections.

1/ Calculations exclude one-off adjustments amounting to 0.1 percent of GDP in 2000 (auction of mobile telephone licenses) and 0.8 percent of GDP in 2004 (mostly the assumption of the debt of the railway operator, RENFE).

2/ Includes one time payment of the disputed debt with Andalucía (0.3 percent of GDP) in 2004. 
Table 4. Spain: Public Sector Debt Sustainability Framework, 1997-2050

I. Baseline medium-term projections

1. Public debt/revenues $1 /$

2. Public debt/GDP $1 /$

3. Change in public debt/GDP 2

4. Net debt-creating flows/GDP $(5+6)$

5. Overall deficit, excluding net interest payments/GDP (=primary deficit)

Revenue and grants/GDP

Noninterest expenditure/GDP $3 /$

6. ' $((\mathrm{r}-\pi)-\mathrm{g}(1+\pi)) /(1+\mathrm{g}+\pi+\mathrm{g} \pi)) \operatorname{debt} / \mathrm{GDP}(8 / 7) 4 /$

7. Adjustment factor: $1+\mathrm{g}+\pi+\mathrm{g} \pi$

8. ' $((\mathrm{r}-\pi)-\mathrm{g}(1+\pi))$ debt/GDP $(9+10)$

9. $(\mathrm{r}-\pi)$ times debt/GDP

10. 'minus $\mathrm{g}(1+\pi)$ times debt/GDP

11. Residual, incl. asset changes, privatization receipts (negative), and valuation changes in external debt /GDP (3-4)

Memorandum items: key macro and external assumptions

Nominal GDP (local currency)

Real GDP growth (in percent per year)

Consumer price index (change, in percent per year)

Exchange rate (LC per US dollar)

Nominal appreciation of local currency against U.S. dollar

GDP deflator (change, in percent per year)

Average interest rate on public debt (percent per year)

Average real interest rate (nominal rate minus change in GDP deflator, percent)

Growth of revenues (deflated by GDP deflator, in percent per year)

Growth of noninterest expenditure (deflated by GDP deflator, in percent per year)

Population (million) $5 /$

Immigration (million) $5 /$

Dependency ratio 6/

II. Stress tests

1. If real interest rate, real GDP growth rate, and primary balance (in percent of GDP)

in 2005-09 are at average of past 10 years

2. If real interest rate in 2005 and 2006 is average plus two standard deviations, others at baseline

3. If real GDP growth rate in 2005 and 2006 is average minus two standard deviations, others at baseline

4. If primary balance (in percent of GDP) in 2005 and 2006 is average minus two standard deviations, others at baseline

5. Combination of 2-4 using one standard deviation shocks

6. One time 30 percent real depreciation in 2005 , others at baseline $7 /$

7. If debt ratio in 2005 rises by (additional) 10 percent of GDP, others at baseline

Memorandum items

Primary deficit (percent of GDP, average of past 10 years)

Primary deficit (percent of GDP, standard deviation of past 10 years)

Real interest rate (nominal rate minus change in GDP deflator, average of past 10 years)

Real interest rate (nominal rate minus change in GDP deflator, standard deviation of past 10 years)

Nominal interest rate (average of past 10 years)

Nominal interest rate (standard deviation of past 10 years)

Real GDP growth rate (average of past 10 years)

Real GDP growth rate (standard deviation of past 10 years)

GDP deflator (average of past 10 years)

GDP deflator (standard deviation of past 10 years)

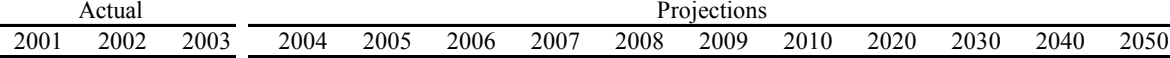

1/ General government defined by ESA-95.

2/ The figures for the years $2020,2030,2040$, and 2050 are also annual changes with respect to the preceding year.

$3 /$ Reflects the most recent official long-run projections for social security expenditure dating from 2001.

4/ Defined as: $r=$ interest rate; $\pi=$ GDP deflator, growth rate; $g=$ real GDP growth rate.

5/Reflects official projections in 2001, which are consistent with the social security expenditure projections.

6/ Defined as the ratio of the population aged 65 and older to those aged 20-64.

7/ Real appreciation is approximated by nominal appreciation against U.S. dollar plus increase in domestic GDP deflator.

$\begin{array}{rrrrrrrrrrrrrr}147.1 & 137.3 & 127.2 & 121.0 & 112.2 & 104.9 & 97.5 & 91.3 & 85.2 & 80.1 & 72.7 & 123.6 & 213.4 & 314.7 \\ 57.8 & 54.4 & 50.7 & \mathbf{4 8 . 4} & \mathbf{4 5 . 0} & \mathbf{4 2 . 0} & \mathbf{3 9 . 0} & \mathbf{3 6 . 4} & \mathbf{3 4 . 0} & \mathbf{3 1 . 7} & \mathbf{2 7 . 9} & \mathbf{4 7 . 8} & \mathbf{8 3 . 3} & \mathbf{1 2 2 . 9} \\ -3.5 & -3.4 & -3.7 & -2.3 & -3.4 & -3.0 & -3.0 & -2.6 & -2.4 & -2.3 & 0.7 & 2.2 & 4.0 & 4.0 \\ -3.5 & -3.5 & -3.5 & -2.1 & -3.2 & -2.7 & -2.8 & -2.5 & -2.3 & -2.2 & 0.8 & 2.2 & 4.0 & 4.0 \\ -2.6 & -2.6 & -2.7 & -1.3 & -2.3 & -2.2 & -2.3 & -2.1 & -2.0 & -1.9 & 0.8 & 2.2 & 4.0 & 4.0 \\ 39.3 & 39.6 & 39.9 & 40.0 & 40.1 & 40.0 & 40.0 & 39.8 & 39.8 & 39.6 & 38.4 & 38.7 & 39.1 & 39.0 \\ 36.4 & 36.8 & 36.9 & 38.4 & 37.5 & 37.6 & 37.5 & 37.6 & 37.7 & 37.5 & 39.1 & 40.9 & 43.0 & 43.0 \\ -1.0 & -0.9 & -0.9 & -0.8 & -0.8 & -0.6 & -0.5 & -0.4 & -0.3 & -0.3 & 0.0 & 0.0 & 0.0 & 0.0 \\ 1.1 & 1.1 & 1.1 & 1.1 & 1.1 & 1.1 & 1.1 & 1.1 & 1.1 & 1.1 & 1.1 & 1.1 & 1.1 & 1.1 \\ -1.0 & -1.0 & -0.9 & -0.8 & -0.9 & -0.6 & -0.5 & -0.4 & -0.3 & -0.4 & 0.0 & 0.0 & 0.0 & 0.0 \\ 0.8 & 0.4 & 0.5 & 0.5 & 0.5 & 0.7 & 0.8 & 0.8 & 0.8 & 0.9 & 0.7 & 1.0 & 1.7 & 2.7 \\ -1.8 & -1.3 & -1.4 & -1.4 & -1.3 & -1.3 & -1.3 & -1.2 & -1.1 & -1.3 & -0.7 & -1.0 & -1.7 & -2.7 \\ 0.1 & 0.1 & -0.2 & -0.3 & -0.2 & -0.2 & -0.2 & -0.1 & -0.1 & 0.0 & -0.1 & 0.0 & 0.0 & 0.0 \\ & & & & & & & & & & & & & \\ 650 & 699 & 745 & 793 & 847 & 900 & 956 & 1015 & 1074 & 1137 & 1937 & 3155 & 5139 & 8370 \\ 2.8 & 2.2 & 2.5 & 2.6 & 2.7 & 2.9 & 3.1 & 3.1 & 3.0 & 2.9 & 2.5 & 2.4 & 2.4 & 2.4 \\ 2.8 & 3.6 & 3.1 & 3.1 & 3.5 & 2.8 & 2.7 & 2.7 & 2.7 & 2.7 & 2.5 & 2.5 & 2.5 & 2.5 \\ 1.1 & 1.1 & 0.9 & 0.9 & 0.9 & 0.9 & 0.9 & 0.9 & 0.9 & 0.9 & 0.9 & 0.9 & 0.9 & 0.9 \\ -2.9 & 5.6 & 17.4 & 0.0 & 0.0 & 0.0 & 0.0 & 0.0 & 0.0 & 0.0 & 0.0 & 0.0 & 0.0 & 0.0 \\ 4.2 & 4.5 & 4.0 & 3.8 & 4.0 & 3.3 & 3.0 & 2.9 & 2.8 & 2.8 & 2.5 & 2.5 & 2.5 & 2.5 \\ 5.4 & 5.2 & 4.9 & 4.9 & 4.9 & 4.9 & 5.0 & 5.0 & 5.0 & 5.0 & 5.0 & 5.0 & 5.0 & 5.0 \\ 1.2 & 0.7 & 0.9 & 1.1 & 1.0 & 1.6 & 1.9 & 2.1 & 2.1 & 2.2 & 2.5 & 2.5 & 2.5 & 2.5 \\ 3.2 & 3.7 & 3.1 & 2.8 & 3.0 & 2.7 & 3.0 & 2.7 & 3.0 & 2.2 & 2.6 & 2.5 & 2.5 & 2.4 \\ 2.2 & 3.8 & 2.9 & 6.7 & 0.4 & 3.2 & 2.7 & 3.4 & 3.3 & 2.4 & 3.0 & 2.4 & 2.5 & 2.4 \\ \ldots & \ldots . & \ldots & \ldots & 40.6 & \ldots & \ldots & \ldots & \ldots & 41.3 & 41.9 & 41.4 & 40.3 & 40.3 \\ \ldots & \ldots . . . & \ldots . . & \ldots & 0.16 & \ldots & \ldots & \ldots & \ldots & 0.16 & 0.16 & 0.16 & 0.16 & 0.16 \\ \ldots & \ldots & \ldots & \ldots & 0.28 & \ldots & \ldots & \ldots & \ldots & 0.30 & 0.34 & 0.43 & 0.56 & 0.56 \\ & & & & & & & & & & & & & \end{array}$

CInternational Monetary Fund. Not for Redistribution 
Table 5. Spain: Updated Stability Program, 2003-08

(In percent of GDP, unless otherwise indicated)

\begin{tabular}{|c|c|c|c|c|c|c|}
\hline & \multirow[b]{2}{*}{2003} & \multicolumn{5}{|c|}{ Program } \\
\hline & & 2004 & 2005 & 2006 & 2007 & 2008 \\
\hline \multicolumn{7}{|c|}{ General government (in percent of GDP) 1/ } \\
\hline Revenue & 40.0 & 39.9 & 39.9 & 40.0 & 40.1 & 40.2 \\
\hline Expenditure & 39.6 & 40.6 & 39.8 & 39.8 & 39.8 & 39.8 \\
\hline Current expenditure & 34.8 & 35.1 & 34.8 & 34.7 & 34.6 & 34.6 \\
\hline Capital expenditure & 4.8 & 5.5 & 5.0 & 5.1 & 5.2 & 5.2 \\
\hline Balance & 0.4 & -0.8 & 0.1 & 0.2 & 0.4 & 0.4 \\
\hline Central Government & -0.3 & -1.8 & -0.5 & -0.4 & -0.3 & -0.3 \\
\hline Social security & 1.0 & 0.8 & 0.7 & 0.7 & 0.7 & 0.7 \\
\hline Territorial governments & -0.3 & 0.2 & -0.1 & -0.1 & 0.0 & 0.0 \\
\hline Gross debt & 50.7 & 49.1 & 46.7 & 44.3 & 42.0 & 40.0 \\
\hline Primary balance & 2.9 & 1.5 & 2.2 & 2.2 & 2.3 & 2.3 \\
\hline \multicolumn{7}{|c|}{ Macroeconomic scenario (growth rates) } \\
\hline Real GDP & 2.5 & 2.6 & 2.9 & 3.0 & 3.0 & 3.0 \\
\hline Private consumption & 2.9 & 3.3 & 3.1 & 3.0 & 2.9 & 2.9 \\
\hline Public consumption & 3.9 & 4.2 & 3.5 & 3.3 & 3.3 & 3.3 \\
\hline Gross fixed capital formation & 3.4 & 5.3 & 5.5 & 4.7 & 4.2 & 4.0 \\
\hline Domestic demand & 3.2 & 4.0 & 3.8 & 3.5 & 3.3 & 3.3 \\
\hline Exports & 2.6 & 5.1 & 6.4 & 6.8 & 6.9 & 6.9 \\
\hline Imports & 4.8 & 8.9 & 8.5 & 7.5 & 7.0 & 6.9 \\
\hline \multicolumn{7}{|l|}{ Other variables } \\
\hline GDP deflator & 4.0 & 3.8 & 3.7 & 3.5 & 3.2 & 2.8 \\
\hline Private consumption deflator & 3.1 & 3.0 & 3.1 & 2.9 & 2.7 & 2.4 \\
\hline Employment & 1.7 & 2.1 & 2.1 & 2.2 & 2.1 & 2.0 \\
\hline \multicolumn{7}{|l|}{ Authorities' low-growth scenario } \\
\hline Real GDP (growth rate) & $\ldots$ & 2.6 & 2.4 & 2.5 & 2.5 & 2.5 \\
\hline General government balance & $\ldots$ & -0.8 & -0.2 & -0.2 & -0.2 & -0.2 \\
\hline Gross debt & $\ldots$ & 49.1 & 47.2 & 45.5 & 43.9 & 42.6 \\
\hline
\end{tabular}

Source: Actualización del Programa de Estabilidad, España 2004-08.

1/ On an ESA95 basis. 
Table 6. Spain: Indicators of External and Financial Vulnerability, 1999-2004 1/

(In percent of GDP, unless otherwise indicated)

\begin{tabular}{|c|c|c|c|c|c|c|c|}
\hline & \multirow[t]{2}{*}{1999} & \multirow[t]{2}{*}{2000} & \multirow[t]{2}{*}{2001} & \multirow[t]{2}{*}{2002} & \multirow{2}{*}{${ }^{2003}$} & \multicolumn{2}{|c|}{2004} \\
\hline & & & & & & $\begin{array}{c}\text { Latest } \\
\text { observation }\end{array}$ & $\begin{array}{r}\text { Date of } \\
\text { sservation }\end{array}$ \\
\hline \multicolumn{8}{|l|}{ External indicators 1/ } \\
\hline Exports (annual percent change, in U.S. dollars) & 3.2 & 2.3 & 3.4 & 8.0 & 24.0 & 12.6 & Jan-Aug \\
\hline Imports (annual percent change, in U.S. dollars) & 8.8 & 5.1 & 0.9 & 7.3 & 25.3 & 20.8 & Jan-Aug \\
\hline Terms of trade (annual percent change) & -0.8 & -2.2 & 2.8 & 2.5 & 1.0 & $\ldots$ & $\ldots$ \\
\hline Current account balance (settlements basis) & -2.3 & -3.4 & -2.8 & -2.4 & -2.8 & -4.1 & Jun \\
\hline Capital and financial account balance & 3.1 & 4.0 & 4.0 & 3.9 & 4.0 & 4.5 & Jun \\
\hline Of which: Inward portfolio investment (debt securities, etc.) & 6.6 & 12.2 & 5.8 & 5.9 & 3.8 & 7.3 & Jun \\
\hline Inward foreign direct investment & 2.3 & 7.8 & 6.0 & 6.1 & 2.4 & 0.6 & Jun \\
\hline Other investment liabilities (net) & 2.5 & 6.9 & 8.5 & 2.2 & 5.3 & -0.4 & Jun \\
\hline Official reserves (in U.S. dollars, billions, end-of-period) 2/ & 33.9 & 31.8 & 30.3 & 35.3 & 37.8 & $\ldots$ & $\ldots$ \\
\hline Central Bank foreign liabilities (in U.S. dollars, billions) 2/ & 80.9 & 86.1 & 76.3 & 78.1 & 67.7 & 65.3 & Sep \\
\hline Foreign assets of the financial sector (in U.S. dollars, billions) & 266.1 & 361.8 & 395.9 & 389.9 & 338.6 & 339.1 & Sep \\
\hline Foreign liabilities of the financial sector (in U.S. dollars, billions) & 441.8 & 585.2 & 648.2 & 664.7 & 639.6 & 658.4 & Sep \\
\hline Official reserves in months of imports $2 /$ & 2.3 & 2.1 & 2.0 & 2.1 & 1.8 & $\ldots$ & $\ldots$ \\
\hline Total external debt & 30.6 & 29.4 & 26.5 & 22.4 & $\ldots$ & $\ldots$ & $\ldots$ \\
\hline Of which: General government debt & 18.9 & 23.1 & 23.5 & 22.8 & $\ldots$ & $\ldots$ & $\ldots$ \\
\hline Total external debt to exports (ratio) & 1.7 & 0.9 & 0.9 & 0.8 & $\ldots$ & $\ldots$ & $\ldots$ \\
\hline Exchange rate (per U.S. dollars, period average) & 0.9 & 1.1 & 1.1 & 1.1 & 0.9 & 0.8 & Sep \\
\hline \multicolumn{8}{|l|}{ Financial market indicators } \\
\hline Public sector debt (Maastricht definition) & 63.1 & 61.3 & 57.8 & 54.4 & 50.7 & $\ldots$ & $\ldots$ \\
\hline 3-month T-bill yield & 3.0 & 4.6 & 3.9 & 3.3 & 2.2 & 2.2 & Sep \\
\hline 3-month T-bill yield (real) & 0.7 & 1.7 & 1.3 & -0.3 & -0.7 & -0.3 & Sep \\
\hline Stock market index ( general) & 894.4 & 994.8 & 853.4 & 723.6 & 706.4 & 917.7 & Nov \\
\hline Share prices of financial institutions & $\ldots$ & $\ldots$ & 1061.1 & 869.9 & 808.7 & 1013.6 & Nov \\
\hline Spread of 3-month T-bills with Germany (percentage points, end-of-period) & 0.1 & 0.3 & 0.3 & 0.4 & 0.2 & 0.1 & Sep \\
\hline \multicolumn{8}{|l|}{ Financial soundness indicators (core set) $3 /$} \\
\hline Regulatory capital to risk-weighted assets & 12.6 & 12.4 & 12.9 & 12.5 & 12.5 & 12.1 & Jun \\
\hline Regulatory Tier I capital to risk-weighted assets & 9.4 & 9.0 & 8.9 & 8.6 & 8.5 & 8.2 & Jun \\
\hline Nonperforming loans net of provisions to Tier I capital 4/ & 15.3 & -2.2 & 1.0 & 3.9 & 4.3 & 2.9 & Jun \\
\hline Nonperforming loans net of provisions to total capital 5/ & -3.6 & -9.3 & -8.5 & -7.6 & -8.9 & -10.9 & Jun \\
\hline Sectoral distribution of loans to resident total & 72.7 & 65.7 & 67.7 & 73.2 & 75.7 & 75.4 & Jun \\
\hline Interbank and central bank & 10.9 & 8.1 & 7.8 & 7.1 & 7.0 & 6.0 & Jun \\
\hline General government & 13.8 & 11.3 & 11.2 & 11.4 & 11.2 & 10.1 & Jun \\
\hline Other sectors & 48.0 & 46.3 & 48.6 & 54.7 & 57.5 & 59.4 & Jun \\
\hline Sectoral distribution of loans to nonresident total & 27.3 & 34.3 & 32.3 & 26.8 & 24.3 & 24.6 & Jun \\
\hline Interbank and central bank & 11.1 & 10.8 & 10.6 & 9.7 & 8.3 & 8.9 & Jun \\
\hline General government & 4.9 & 9.5 & 8.0 & 5.8 & 5.3 & 5.1 & Jun \\
\hline Other sectors & 11.3 & 14.1 & 13.7 & 11.3 & 10.7 & 10.5 & Jun \\
\hline Return on assets & 0.99 & 1.04 & 0.97 & 0.87 & 0.94 & 1.03 & Jun \\
\hline Return on equity & 15.87 & 15.52 & 13.87 & 12.3 & 13.72 & 15.75 & Jun \\
\hline Interest margin to gross income & 70.23 & 68.77 & 70.57 & 71.20 & 69.03 & 69.29 & Jun \\
\hline Noninterest expense to gross income & 64.76 & 62.97 & 60.31 & 59.10 & 57.09 & 55.21 & Jun \\
\hline Liquid assets to total assets (liquid asset ratio) & 39.2 & 37.2 & 35.5 & 33.0 & 32.3 & 31.4 & Jun \\
\hline Liquid assets to short-term liabilities & 75.4 & 78.0 & 76.0 & 71.5 & 69.5 & 68.2 & Jun \\
\hline Net open position in foreign exchange to Tier I capital & 22.1 & 23.5 & 23.1 & 12.9 & 8.3 & 8.5 & Jun \\
\hline
\end{tabular}

Sources: Bank of Spain, Economic Bulletin and Statistical Bulletin; data provided by the authorities; and IMF, International Financial Statistics.

1/ The interpretation of some indicators is affected by the launch of monetary union in 1999.

2/ Reserves and foreign liabilities refer to the Bank of Spain, both before and after EMU.

3/ For consolidated domestic deposit takers; indicators are expressed as ratios.

4/ NPLs net of specific provisions (i.e. excludes generic and statistical provisions).

5/ NPLs net of all provisions (specific, generic, and statistical). 
Figure 1. Spain: Real Sector, 2000-04

Real GDP Growth

(Year-on-year percentage change)
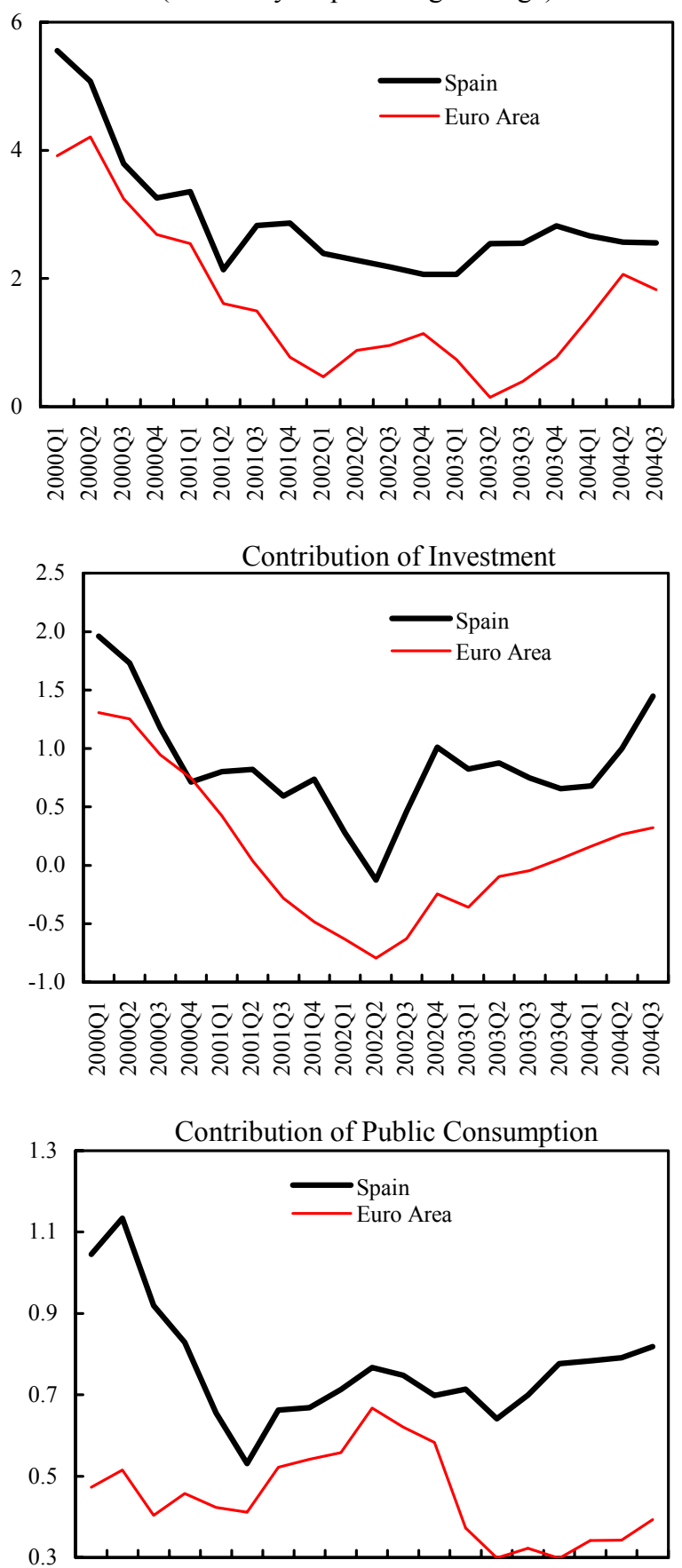

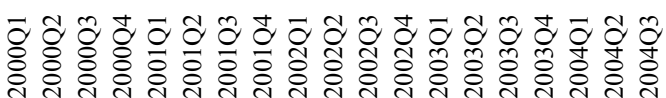

Per Capita Income as a Share of Average for Euro Area
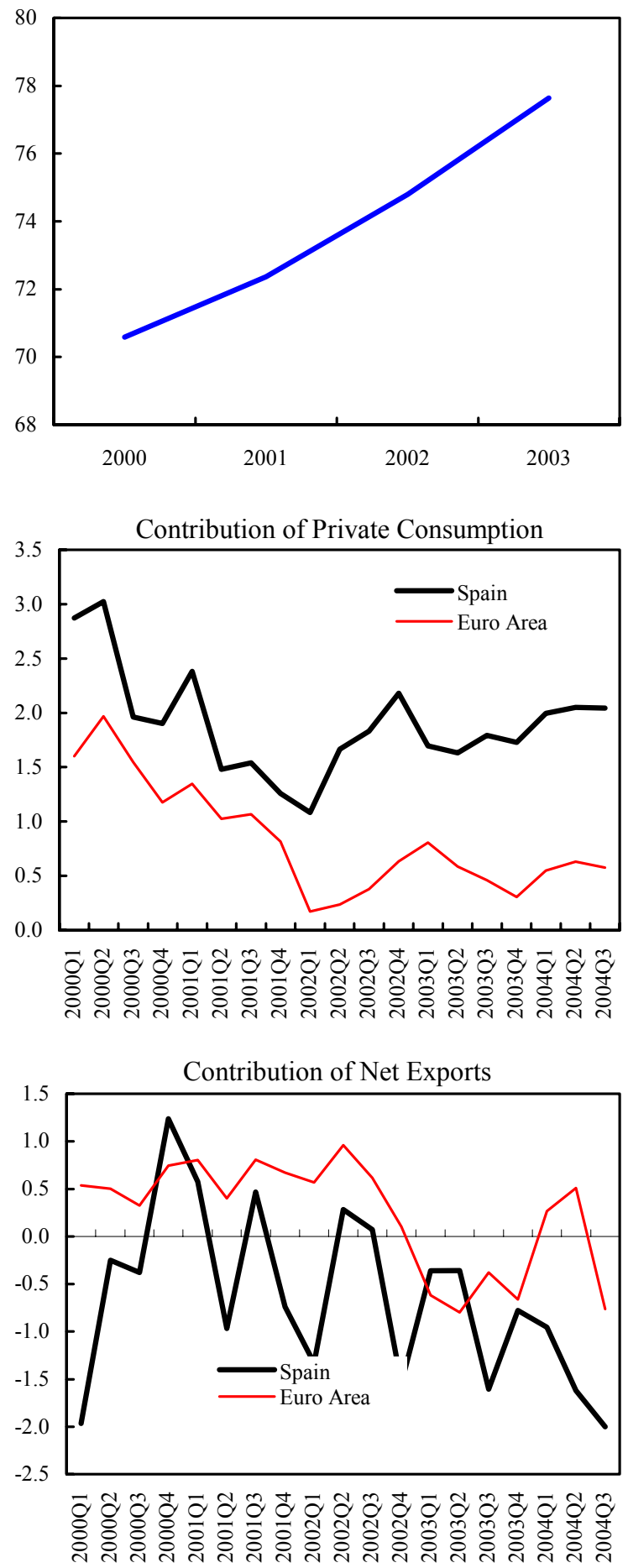

Sources: Bank of Spain and Eurostat. 
Figure 2. Spain: Headline and Core Inflation, 1997-2004 (In percent)

HICP

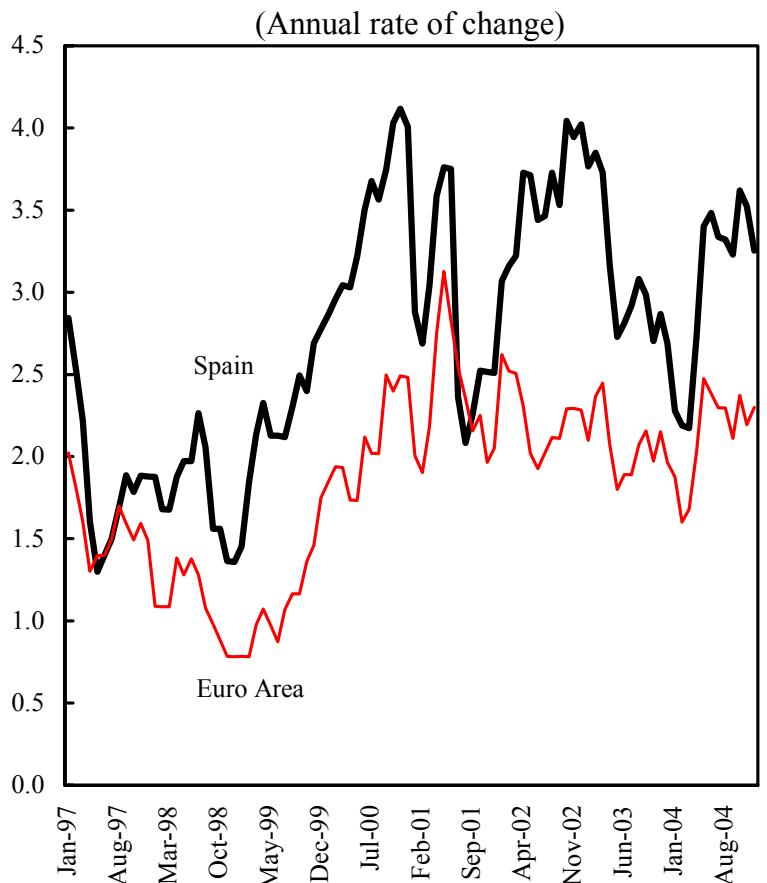

Differential for Spain vs. Euro Area

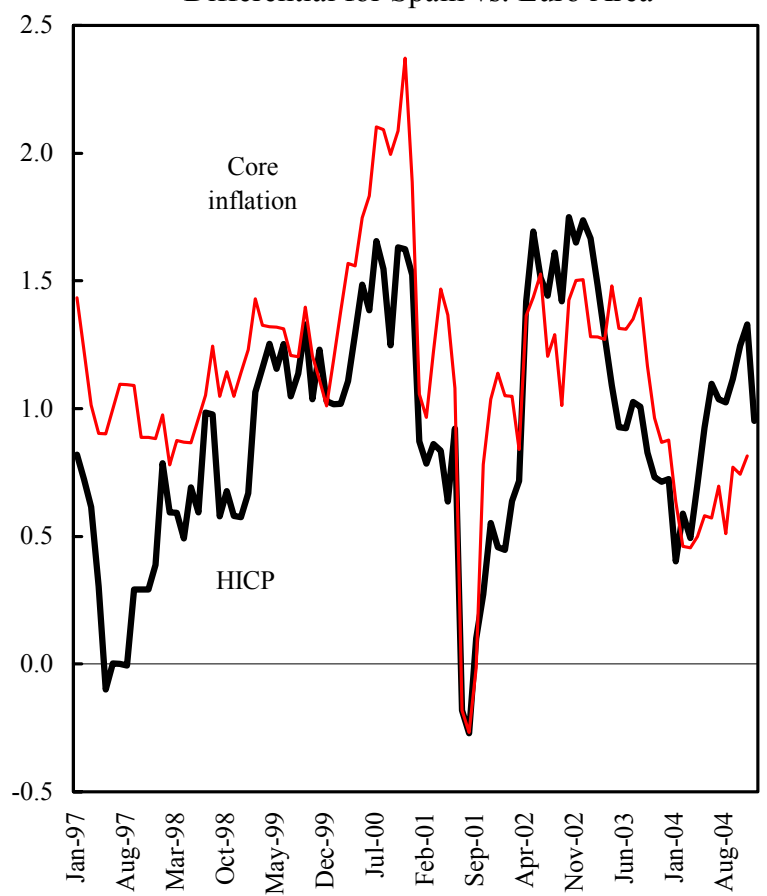

Core Inflation

(Annual rate of change)

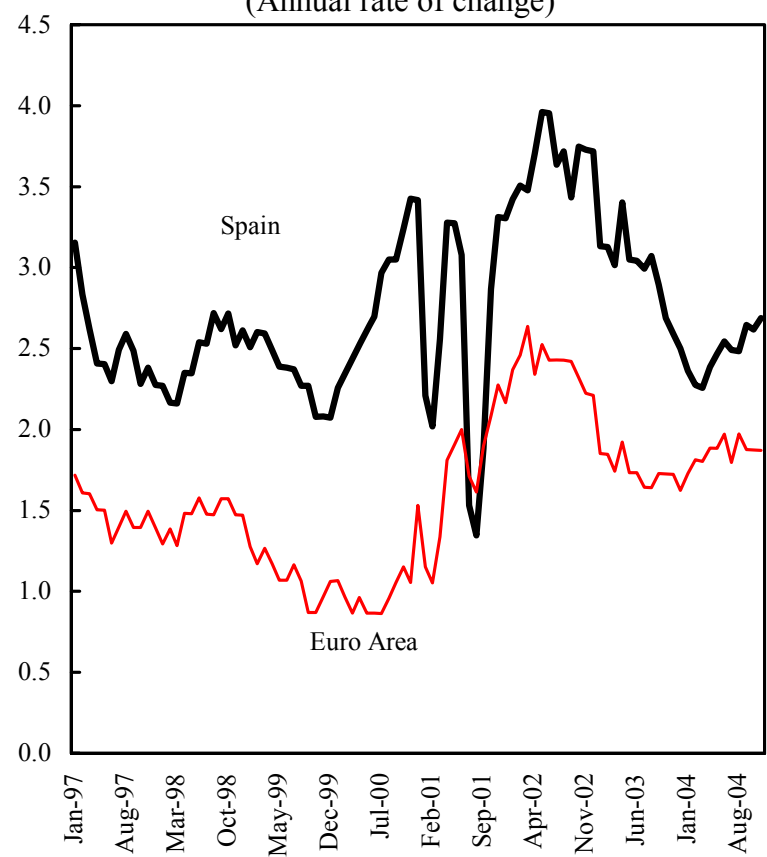

Cumulative Differential for Spain vs. Euro

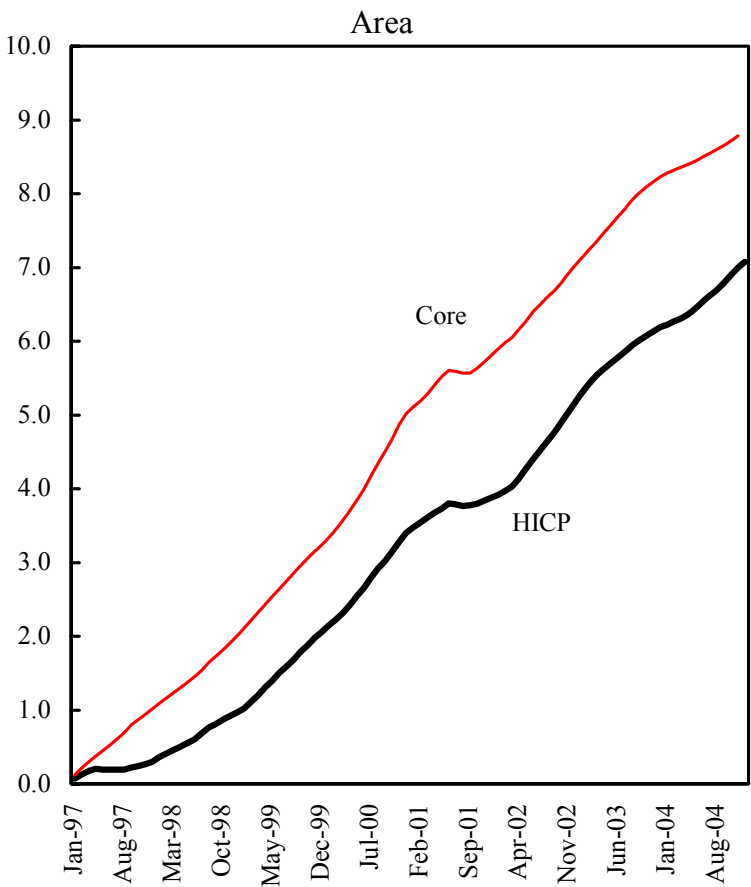

Source: Eurostat. 
Figure 3. Spain: Competitiveness and Exports, 1990-2004
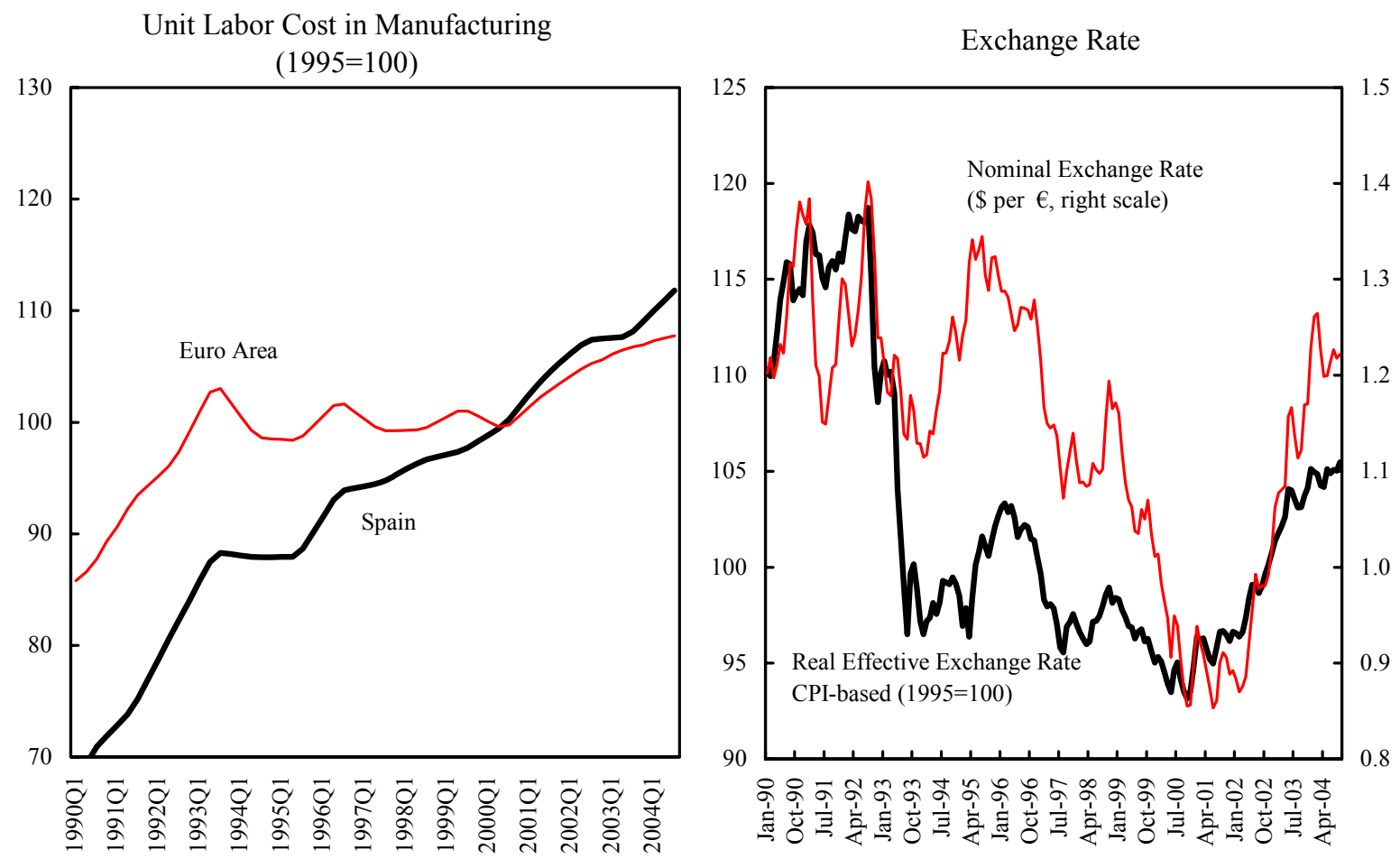

Export Market Share of Euro Area imports

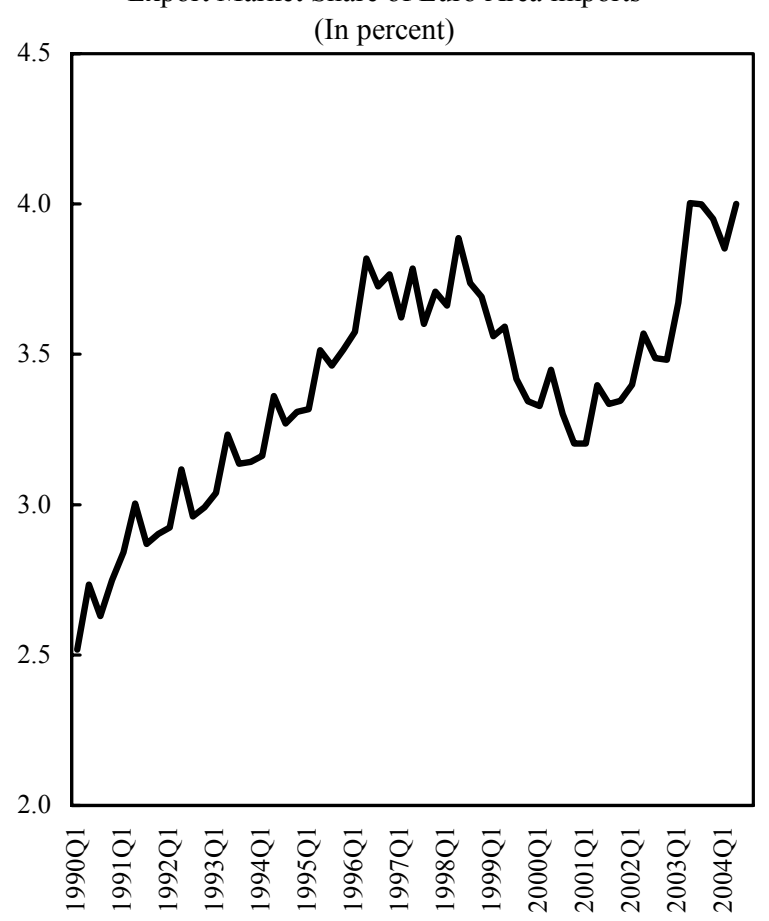

Export Market Share 1/

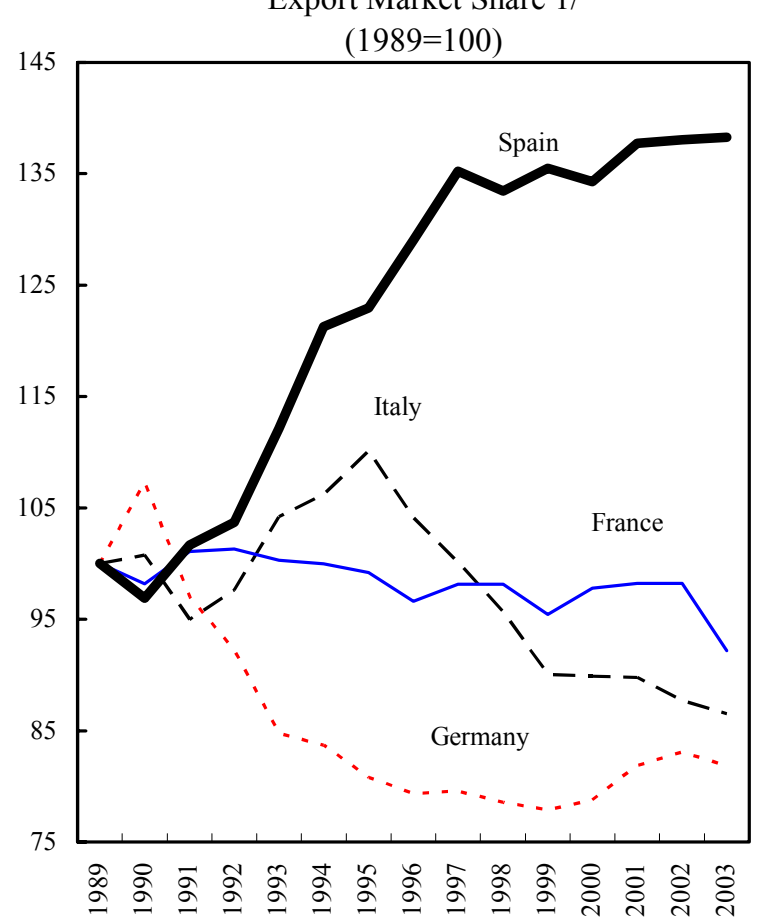

Sources: IMF, International Financial Statistics; IMF, Direction of Trade; IMF, World Economic Outlook; Bank of Italy; ISTAT; and Organization for Economic Cooperation and Development.

1/ As measured by real growth of exports of goods and nonfactor services less growth of import demand in partner countries. 
Figure 4. Spain: Demographic Shock and Health Spending

Number of Children per Woman

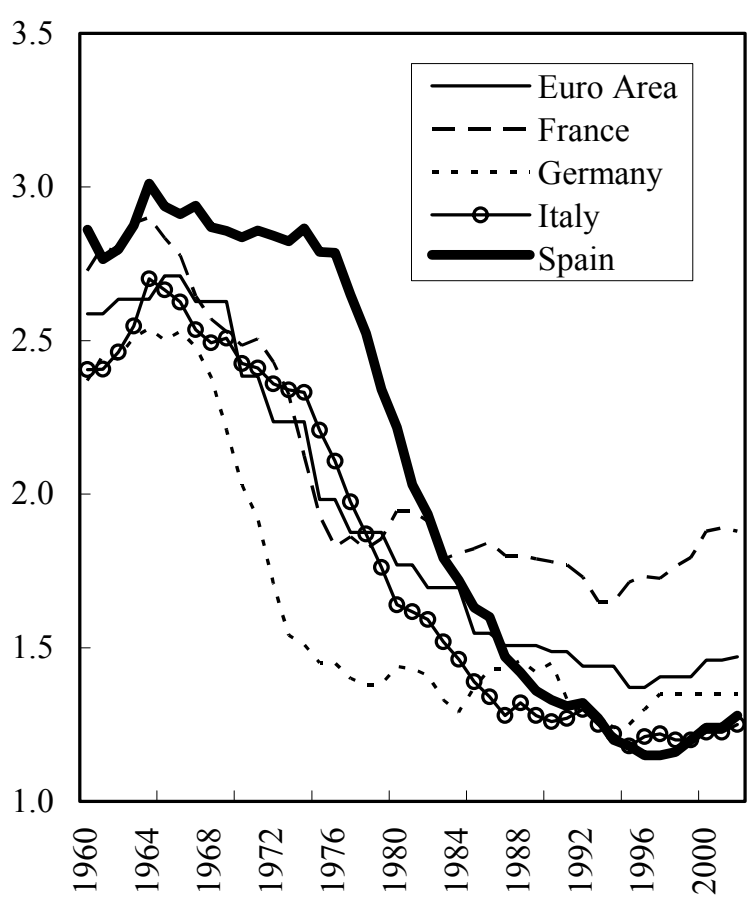

Health Expenditure by Age Group

(In percent of GDP per capita)

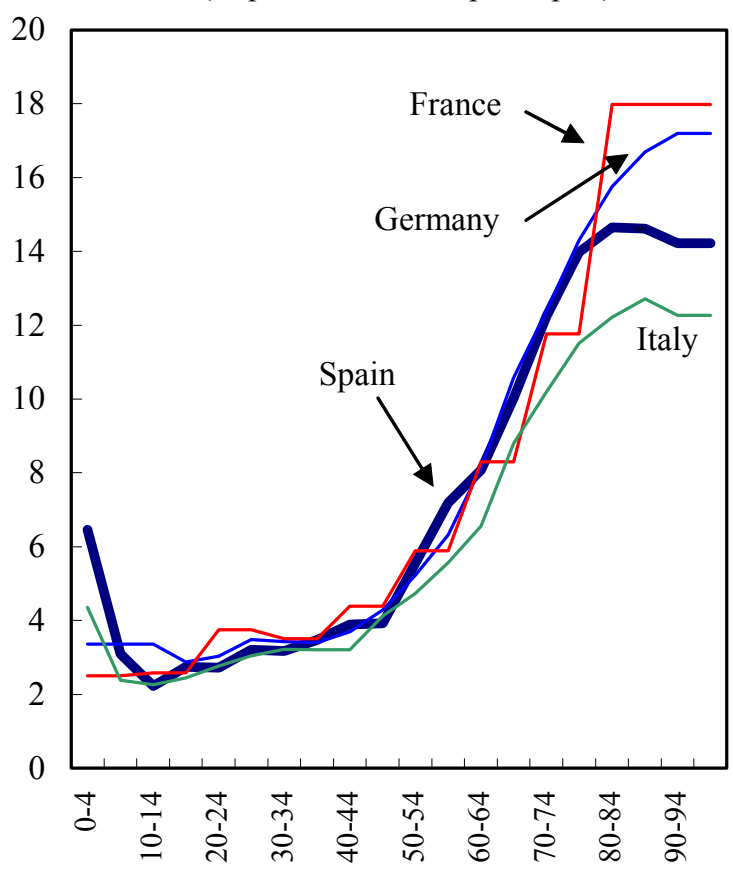

Life Expectancy

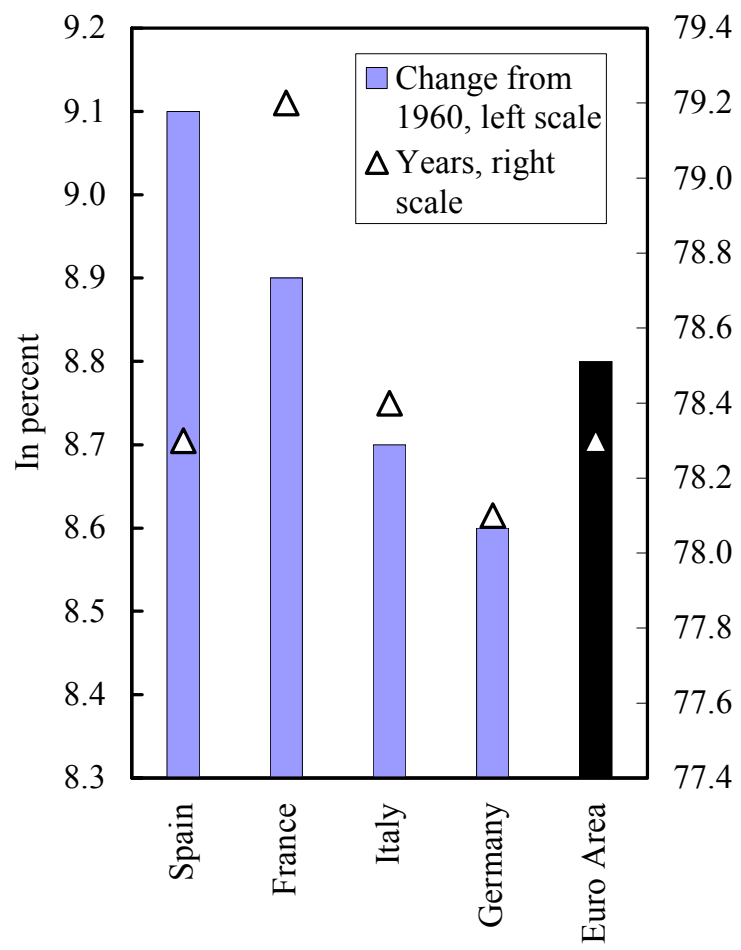

Health Spending and Aging

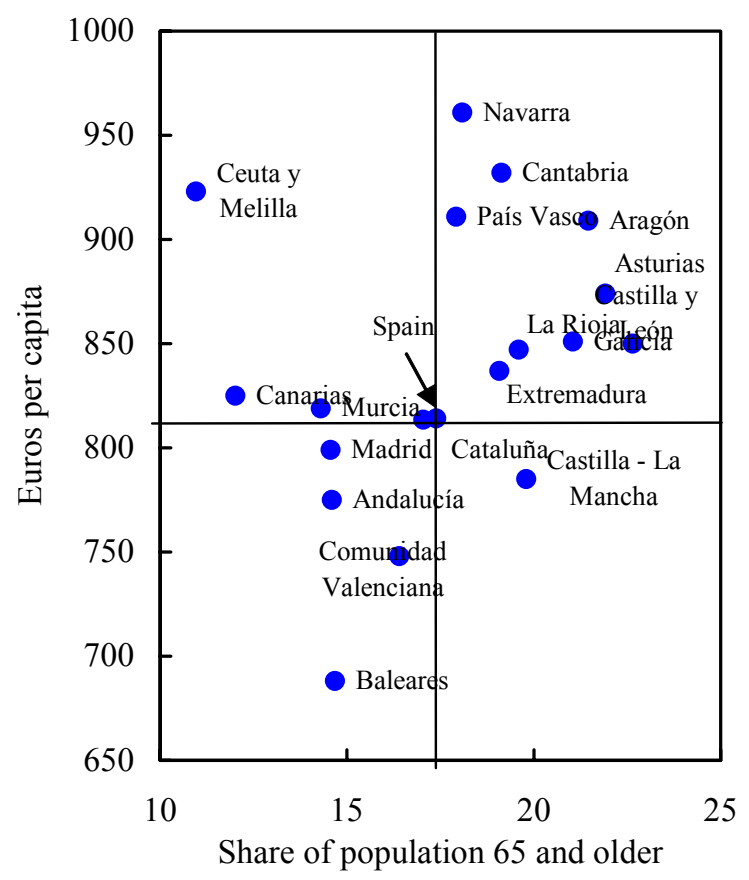

Sources: World Bank, World Development Indicators 2004 and OECD working paper, Spending on Health and Long-term Care: Projections to 2050 Revisited. 
Figure 5. Spain: Convergence, and Labor Productivity and Utilization, 1970-2003

( In percent of euro area)

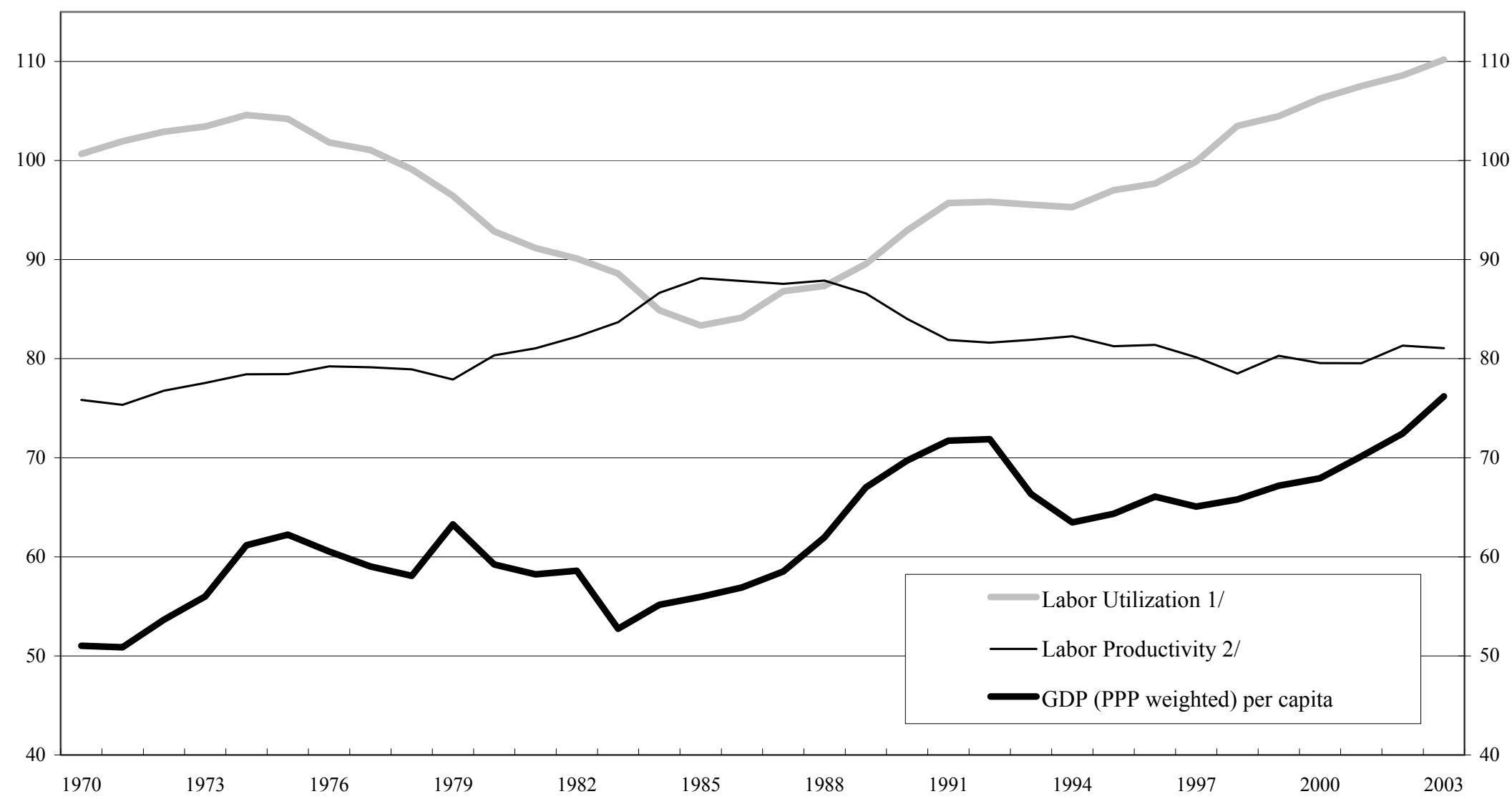

Source: Eurostat; OECD; and Fund staff estimates.

$1 /$ Total hours worked per capita.

2/ GDP (PPP weighted) divided by total hours worked. 


\section{Spain: Fund Relations \\ (As of December 31, 2004)}

I. Membership Status: Spain became a member of the Fund on September 15, 1958. On July 15, 1986, Spain accepted the obligations of Article VIII Sections 2, 3, and 4 of the Articles of Agreement.

II. General Resources Account:

$\begin{array}{ll}\text { SDR Million } & \text { \% Quota } \\ 3,048.90 & 100.00 \\ 2,034.64 & 66.73 \\ 1,014.29 & 33.27\end{array}$

III. SDR Department:

Net cumulative allocation

SDR Million

298.81

213.96
$\%$ Allocation

100.00

71.61

IV. Outstanding Purchases and Loans: None

V. Financial Arrangements: None

VI. Projected Obligations to Fund: (SDR Million; based on existing use of resources and present holdings of SDRs)

\begin{tabular}{lccccc}
\hline & \multicolumn{5}{c}{ Forthcoming } \\
\cline { 2 - 6 } & 2005 & 2006 & 2007 & 2008 & 2009 \\
\hline Principal & & & & & \\
Charges/Interest & 1.67 & 1.91 & 1.91 & 1.91 & 1.91 \\
$\quad$ Total & 1.67 & 1.91 & 1.91 & 1.91 & 1.91 \\
\hline
\end{tabular}

VII. Exchange Rate Arrangement: Spain entered the final stage of European Economic and Monetary Union on January 1,1999, at a rate of 166.386 Spanish pesetas per euro.

Spain maintains an exchange system free of restrictions on the making of payments and transfers for current international transactions, except for the exchange restrictions imposed by Spain solely for the preservation of national or international security that have been notified to the Fund pursuant to Executive Board Decision No. 144-(52/51) (EBD/04/16 and EBD/05/5). Those exchange restrictions are contained in Council Regulations (EC):

- No. 2488/2000 of 10 November 2000, as amended, maintaining a freeze of funds in respect of Mr. Slobadan Milosevic and people associated with him.

- No. 2580/2001 of 27 December 2001, as amended, on specific restrictive measures directed against certain persons and entities with a view to combating terrorism.

- No. 881/2002 of 27 May 2002, as amended, imposing certain restrictive measures directed against certain persons and entities associated with Osama bin Laden, the Taliban and the Al-Qaida network.

- No. $1210 / 2003$ of 7 July 2003 , as amended, concerning certain specific restrictions on economic and financial relations with Iraq. 
- No. 314/2004 of 19 February 2004, as amended, concerning certain restrictive measures in respect of Zimbabwe.

- No. 798/2004 of 26 April 2004, as amended, renewing the restrictive measures in respect of Burma/Myanmar.

- No. 872/2004 of 29 April 2004, as amended, concerning freezing of funds and economic resources of persons and entities associated with Liberia's former President Taylor.

- No. 1763/2004 of 11 October 2004, as amended, imposing certain restrictive measures in support of effective implementation of the mandate of the International Criminal Tribunal for the Former Yugoslavia.

VIII. Article IV Consultations: The last Article IV consultation was concluded on February 11, 2004. Spain is on the standard 12-month consultation cycle. 


\section{Adjustments to Fiscal Accounts}

Three main changes were made:

- RENFE debt. To comply with new railway legislation coming into effect in December 2004 - whereby the construction and operation of railways are to be managed by distinct entities - capital transfers will be used to pay off 80 percent of the operator's (RENFE) debt.

- RTVE debt. To recognize the debt of the heavily indebted public radio and television corporation (RTVE).

- Argentina loan. To write-off partially the 2001 bilateral loan to Argentina was charged in 2004; smaller charges are envisaged in 2005-06.

In addition, the central government settled Andalucia's disputed debt from the subnational financing agreement in place before 2001. This affects the composition of the deficits but not the general government balance

2004 Fiscal Accounts: One-Time Adjustments

\begin{tabular}{lcc}
\hline & Billion Euros & Percent of GDP \\
& & -0.8 \\
\hline Headline General Government Balance & -6.0 & -1.8 \\
Central Government & & 0.8 \\
Social Security & & 0.2 \\
Sub-National Government & & 1.1 \\
Expenditure Adjustments to the Central Government & 9.0 & 0.7 \\
RENFE & 5.6 & 0.1 \\
RTVE & 0.6 & 0.0 \\
Argentina Loan & 0.3 & 0.3 \\
Andalucia Debt & 2.5 & -0.3 \\
Revenue Adjustment to the Sub-National Government & & \\
Andalucia Debt & -2.5 & 0.1 \\
$\quad$ & 0.5 & -0.7 \\
General Government Balance (excluding adjustments) & & -0.1 \\
Central Government 1/ & & \\
Social Security & & \\
Sub-National Government & & \\
&
\end{tabular}

Sources: Ministry of Economy, and staff estimates.

$1 /$ Corresponds to -0.4 percent of GDP on a cash basis. 


\section{Spain: Statistical Issues}

Areas for improvement include:

- General government. Historical revisions, preliminary estimates, and planned fiscal accounts data should be made available to the public shortly after being sent to Eurostat in March and September. In addition, major revisions should be fully documented. Although the 2005 budget included a reconciliation of the budget and national accounts presentations, details could be added to further clarify the reconciliation. Details of these calculations would enhance monitoring at higher frequencies. The statistical nature and impact of a large multi-year investment project for national roads, announced to be outside the budget, should be reflected appropriately in the statistical treatment of general government accounts.

- Territorial governments. The timeliness of fiscal outcomes improved with the publication of 2003 fiscal balances on September 14, 2004, but expenditure and revenue details remain wanting. The importance of monitoring fiscal developments at the territorial level is heightened by considerable expenditure decentralization, and recent deviations from their fiscal targets, and is essential for the implementation of the Budgetary Stability Law.

- Labor market. Two different measures of unemployment are reported by the authorities (so-called "registered" and "survey" unemployment), which vary substantially. Data on employment growth are distorted by the flow of workers from the informal to the formal labor force, which complicates the calculation of productivity growth and hence unit labor costs.

- National Accounts. These have been revised in line with the 1995 version of the European System of Accounts, but pre-1995 data have not been revised yet. 
Spain: Core Statistical Indicators

(As of January 18, 2005)

\begin{tabular}{|c|c|c|c|c|c|c|c|c|c|c|c|}
\hline & $\begin{array}{l}\text { Exchange } \\
\text { Rates }\end{array}$ & $\begin{array}{c}\text { International } \\
\text { Reserves }\end{array}$ & $\begin{array}{l}\text { Central Bank } \\
\text { Balance Sheet }\end{array}$ & $\begin{array}{l}\text { Broad } \\
\text { Money }\end{array}$ & $\begin{array}{l}\text { Interest } \\
\text { Rates }\end{array}$ & $\begin{array}{l}\text { Consumer } \\
\text { Price Index }\end{array}$ & $\begin{array}{l}\text { Exports/ } \\
\text { Imports }\end{array}$ & $\begin{array}{c}\text { Current } \\
\text { Account } \\
\text { Balance }\end{array}$ & $\begin{array}{c}\text { Overall } \\
\text { Government } \\
\text { Balance 1/ }\end{array}$ & GDP/GNP & $\begin{array}{c}\text { External } \\
\text { Debt 2/ }\end{array}$ \\
\hline $\begin{array}{l}\text { Date of Latest } \\
\text { Observation }\end{array}$ & $1 / 18 / 05$ & $11 / 04$ & $12 / 04$ & $11 / 04$ & $1 / 18 / 05$ & $12 / 04$ & $11 / 04$ & $10 / 04$ & 2003 & Q3/2004 & Q3/2004 \\
\hline Date Received & $1 / 18 / 05$ & $12 / 04$ & $1 / 05$ & $12 / 04$ & $1 / 18 / 05$ & $01 / 05$ & $01 / 05$ & $01 / 05$ & $3 / 04$ & $12 / 04$ & $12 / 04$ \\
\hline $\begin{array}{l}\text { Frequency of } \\
\text { Data }\end{array}$ & Daily & Monthly & Monthly & Monthly & Daily & Monthly & Monthly & Monthly & Annual & Quarterly & Quarterly \\
\hline $\begin{array}{l}\text { Frequency of } \\
\text { Reporting }\end{array}$ & Daily & Monthly & Monthly & Monthly & Daily & Monthly & Monthly & Monthly & Annual & Quarterly & Quarterly \\
\hline $\begin{array}{l}\text { Source of } \\
\text { Update }\end{array}$ & Central bank & Central bank & Central bank & $\begin{array}{c}\text { Central bank; } \\
\text { Reuters }\end{array}$ & Central bank & $\begin{array}{l}\text { National } \\
\text { Institute of } \\
\text { Statistics; } \\
\text { Reuters }\end{array}$ & $\begin{array}{c}\text { Central bank; } \\
\text { Reuters }\end{array}$ & $\begin{array}{c}\text { Central bank; } \\
\text { Reuters }\end{array}$ & $\begin{array}{l}\text { Ministry of } \\
\text { Finance }\end{array}$ & $\begin{array}{l}\text { National } \\
\text { Institute of } \\
\text { Statistics; } \\
\text { Reuters }\end{array}$ & Central bank \\
\hline $\begin{array}{l}\text { Mode of } \\
\text { Reporting }\end{array}$ & Electronic & $\begin{array}{l}\text { Electronic, } \\
\text { tape and } \\
\text { publication }\end{array}$ & $\begin{array}{l}\text { Electronic, } \\
\text { tape and } \\
\text { publication }\end{array}$ & $\begin{array}{l}\text { Electronic, } \\
\text { tape and } \\
\text { publication }\end{array}$ & $\begin{array}{l}\text { Electronic, } \\
\text { tape and } \\
\text { publication }\end{array}$ & $\begin{array}{c}\text { Electronic and } \\
\text { publication }\end{array}$ & $\begin{array}{l}\text { Electronic, } \\
\text { tape and } \\
\text { publication }\end{array}$ & $\begin{array}{l}\text { Electronic, } \\
\text { tape and } \\
\text { publication }\end{array}$ & $\begin{array}{c}\text { Tape and } \\
\text { publication }\end{array}$ & $\begin{array}{c}\text { Electronic, } \\
\text { tape and } \\
\text { publication }\end{array}$ & $\begin{array}{l}\text { Electronic, } \\
\text { tape and } \\
\text { publication }\end{array}$ \\
\hline $\begin{array}{l}\text { Confidentialit } \\
\text { y }\end{array}$ & Public & Public & Public & Public & Public & Public & Public & Public & Public & Public & Public \\
\hline $\begin{array}{l}\text { Frequency of } \\
\text { Publication }\end{array}$ & Daily & Monthly & Monthly & Monthly & Daily & Monthly & Monthly & Monthly & Annual & Quarterly & Quarterly \\
\hline
\end{tabular}

1/ Central government balance is released to the press monthly, about three weeks after the end of the month, and published by the Ministry of Finance.

2/ Spanish government debt held by nonresidents is released to the press weekly by the central bank and drawn by staff from Reuters 


\section{Statement by Moises Schwartz, Executive Director for Spain and Pablo Moreno, Senior Advisor to Executive Director February 9, 2005}

Our authorities appreciate the candid and constructive dialogue held with the staff during the Article IV mission. The staff has produced a high quality set of papers that provide a very useful contribution to the economic policy debate and the ongoing reform agenda; the authorities will take careful note of their comments.

\section{ECONOMIC PROSPECTS}

In 2004 the Spanish economy grew around 2.6 percent. Unemployment rate has continued its downward trend and it is now at 10.38 percent, the lowest since 2001. In 2005, the authorities are projecting GDP growth at 2.9 percent, slightly higher than staff's estimate. A larger contribution to growth from investment and a lesser drag of the external sector will contribute to this improved short-term prospect. The sharp acceleration on equipment investment registered in the second half of last year is expected to keep its pace in 2005 sustained on strong domestic demand, accelerated exports, favorable financial conditions, and the realized need for technological renovation.

The Consensus Forecast for inflation in 2005 is now in the range of [2.5, 3.0]; our authorities expect that CPI inflation will be on the lower limit. Latest data on January HIPC inflation already reflects a downward trend, and updated information on wage indexation also indicates more moderation than expected. Additionally, the combination of better balanced pattern of growth, a mitigated impact of higher oil prices, and the effects of the appreciation of the euro, point to a more benign inflation forecast.

\section{POLICY FRAMEWORK}

The new government that took office last April has designed an economic policy framework structured around three basic axes:

- Budgetary stability: there is a firm commitment to ensure short- and medium-term budget consolidation as the basis for sustainable growth. This commitment is founded on a widely spread recognition within the public opinion and across political actors of the benefits of fiscal stabilization. Efforts will focus on strengthening the Budgetary Stability Law (to be renamed Budget Stability and Transparency Law, BSTL) by introducing two new elements: (i) applying the principle of stability over the cycle, thereby avoiding procyclical fiscal policy; and (ii) strengthening the transparency of the fiscal framework and anchoring its observance through all levels of government. Staff's comments have largely focused on this area.

- A boost to productivity: Spanish strong economic growth in the past few years has had a major drawback: the weak contribution of productivity to growth. The new government has put in place a strategy that should serve the goal of boosting productivity growth. This 
strategy is built around a combined action in multiple fronts including: increasing public spending in education, $R \& D$ and technological innovation, reinforcing competitiveness in product markets, labor market reform, improving the investment climate, and modernizing the Competition Authority.

- Transparency and quality of the regulatory framework: the new government has embraced a widespread application of the principle of transparency as a central element to enhance the efficiency of the public sector and to foster a predictable framework for private agents. The principle of transparency has already been applied to areas such as the budget, economic data provided by the government (recently approved guidelines require on-line availability of economic and financial data to be provided according to predetermine calendars), good-governance practices in the public sector (a new Code of Good Governance has been approved), and enhancing the transparency of regulatory procedures (which will have to be accompanied by an assessment of their economic rationale and budgetary impact).

This triple-axed policy framework is to be developed in an environment characterized by shared economic responsibilities between central and regional governments. The 1978 Spanish Constitution provides a framework that allows territorial authorities to assume competence over a number of economic policy actions (which should nonetheless be consistent with the general principles of economic policy set up by the central government).

The Constitutional arrangement has led to a profound transformation of the Spanish economic policy in the last 25 years with a progressive transfer of economic policy domains to territorial authorities, placing Spain among the highest decentralized economies in Europe. A non-exhaustive list of competences in the hands of territorial authorities includes: the provision of education and health, control of over 70 percent of the general government budget (excluding social security), taxing capacity, labor market active policies, and product and service market regulation. The staff rightly stresses in many instances throughout the report, specially when referring to the fiscal framework and retail distribution problems, the central role of territorial authorities in undertaking reforms.

This decentralized legal framework limits the ability of the central government to impose economic regulations. Enforceability of economic policy should thereby be reliant in other means, mainly through consensus and coordination with territorial authorities to improve regional ownership of economic policy. In this context, elements such as transparency and peer pressure play a central role. The government has enhanced the institutional framework for coordination with regional authorities by creating a Summit of Presidents of Comunidades Autónomas, that complements existing sector coordination bodies at the ministerial level. The government will also pursue the reform of the Senate to better adapt it to the regional reality.

\section{FISCAL POLICY}

The final 2004 budget incorporates additional payment commitments assumed by the new government (including accounting adjustments in line with ESA-95 and the debt of the public railways entity, RENFE) which shall bring the general government deficit to 
0.8 percent. Excluding these one-off measures, the 2004 general government position would have been close to balance implying a broadly neutral fiscal policy.

The 2005 budget projects a surplus of 0.1 percent of GDP, which is estimated to increase up to 0.4 percent of GDP by 2008 (see Stability Program Update ${ }^{1}$ ), as expenditures remain constant in GDP terms and revenues will increase with economic growth given the progressive nature of the tax system. In cyclically-adjusted terms, these numbers will imply a restrictive stance in 2005 and a broadly neutral fiscal policy in 2006-2008. It is also worth noting that, in line with the objective of boosting productivity, the government has readjusted expenditure in favor of $R \& D$ (to be doubled in four years), education, and infrastructure.

The 2005 budget already incorporates new transparency measures such as the reconciliation of the budget with national accounts and the inclusion of information on potential risks from public enterprises. Transparency measures will be taken further with the new BSTL. The fiscal ROSC, which has found Spain to fully meet or exceed transparency standards, provides a timely input for the ongoing fiscal transparency reform.

The Staff makes many interesting suggestions to the reform of the BSTL, including in the Selected Issues paper on fiscal discipline. Given the principle of financial autonomy recognized in the Constitution, many of the proposals (such as the rainy day funds or expenditure ceilings for regions) can only be undertaken by regional governments themselves, since the central government cannot impose them. The specifics of the reform are still under analysis; here we would stress two considerations in response to the staff's comments on political economy issues and the need to ensure fiscal stability: (i) the reform will be undertaken through a process of permanent dialogue with territorial authorities, and (ii) the law will preserve the objective of budget equilibrium and/or surplus as the central scenario, with deficits being the exception to be justified because of cyclical considerations. The BSTL will include features that will enable regional authorities to operate a cyclesensitive budget thereby increasing their co-responsibility to fiscal stabilization.

The Selected Issues paper on pension reform provides a useful analysis of the effects of alternative approaches to deal with the fiscal costs of aging. The absolute magnitude of this phenomenon needs to be reviewed in light of the new data on national accounts and productivity, and the uncertain effects of the significant demographic changes due to immigration (updated estimates for the population in the year 2050 have increased from 41 to 53 million people). The Economic Policy Committee is working on the new projections of expenditure related to population aging which will be available in mid-2005. Regardless of the new scenario, the authorities are well aware that, even in the most favourable demographic situation, the budgetary burden of an aging population will eventually increase. To safeguard the long-term sustainability of the public finances, the new government structures its strategy around three main lines consistent with the staff's view: (i) budgetary discipline, with the social security surplus to be allocated to the Social Security Reserve Fund (which will reach a 3 percent of GDP on 2005); (ii) sustained growth in GDP and

\footnotetext{
${ }^{1}$ 2004-2008 Stability Program Update: http://www.mineco.es/sgpc/TEXTOS/ProgEst/stabprog.pdf.
} 
employment; and (iii) structural actions on pensions in line with the Pacto de Toledo recommendations.

\section{STRUCTURAL ISSUES}

The strong financial position of the banking system is rooted on prudent management of financial institutions coupled with a supportive regulatory and supervisory framework. Financial supervision will be reinforced with a new bill on financial conglomerates that includes a more updated distribution of competences between the supervisory bodies and the creation of a coordinator figure (the bill will be effective next April, and adapts the 1992 regulation on financial conglomerates to the new EU Directive on this matter). On provisioning, the Bank of Spain issued a circular in force since January 1, 2005, adopting the International Financial Reporting Standards (IFRS). In the new system, generic and "statistical" provisions are merged and there is a slight decrease in the current level of provisions, which will nonetheless remain among the highest in Europe.

Avoiding any room for complacency, the authorities closely monitor market vulnerabilities including those associated with the expansion of real estate-related lending. Here, there is margin for confidence as loan-to-value ratios are typically 80 percent (and far less on average), and the authorities estimate that households could undergo interest rates increases up to 300 basis points, before experiencing loan repayment difficulties. Even in such an unlikely scenario, market flexibility gives households ample maneuver to anticipate changes in financing conditions by redesigning their mortgage contracts. The authorities are focusing on ensuring full transparency of market options and on setting up the conditions for a diversification in the risk profile of outstanding mortgage debt through greater use of fixed or semi-fixed rate loans.

The authorities look forward to the findings of the FSAP scheduled for 2005 which shall provide a useful input to further strengthen the Spanish financial system.

Further improvement of the functioning of the labor market remains a central priority of the authorities and the social partners as expressed in the joint 2004 Social Dialogue Declaration on Competitiveness, Employment and Social Cohesion. The Declaration defines thirteen priority areas that should focus reform efforts on the labor market including: reducing the prevalence of fixed-term contracts, improving female employability, adapting collective bargaining to productivity considerations, increasing the minimum wage, and enhancing labor market active policies. The staff diagnosis on theses issues will be useful.

The 2004 Progress Report on Economic Reform of Product and Capital Markets ${ }^{2}$ reviews the ongoing product market reforms. The authorities are developing a comprehensive Competition Plan focused on sector liberalization measures. Among the initiatives underway,

\footnotetext{
${ }^{2} 2004$ Progress report on Economic Reform of Product and Capital Markets: http://www.mineco.es/sgpc/TEXTOS/documentos/prrgscm_nov_2004.pdf.
} 
it is worth stressing the modernization of the competition system. The reform will create by the end of 2005 an independent and better funded National Commission of Competition that will integrate the current instruction and resolution bodies, maintaining nonetheless the independence of both procedures. We would again stress here the role to be played by territorial authorities on product market reform, as pointed out by staff when referring to retail distribution.

The new government has placed the reform of the housing market as one of its key priorities on the political agenda (explicitly signaled with the creation of a new Housing Ministry). Notwithstanding the risks introduced by the boom in housing prices in the last few years, it should be highlighted that price increases have been backed by fundamentals, with supply at historical records but not keeping up with the pace of demand (last year has marked yet another construction record with an estimated 675,000 new homes built). Housing prices in 2004 are already showing signs of a decelerating trend and the authorities expect an orderly stabilization of prices in the coming years with limited impact on the economy (Box 2 on the staff paper provides a stress-test that reflects limited impact even in worse case scenarios of absolute price declines). In order to favor this orderly adjustment, the authorities have undertaken a package of urgent measures in 2005 , focused on promoting the rental market and increasing the supply of social housing. The government is now working on a more comprehensive strategy that will consider fiscal measures and a reform to the law on land use. 
Public Information Notice (PIN) No. 05/22

FOR IMMEDIATE RELEASE

February 17, 2005
International Monetary Fund

$70019^{\text {th }}$ Street, NW

Washington, D. C. 20431 USA

\section{IMF Executive Board Concludes 2004 Article IV Consultation with Spain}

On February 9 2005, the Executive Board of the International Monetary Fund (IMF) concluded the Article IV consultation with Spain. ${ }^{1}$

\section{Background}

With growth proceeding at a steady pace of 2.6 percent during 2004, the Spanish economy has weathered the slowdown in the EU relatively well. Output growth has remained above the euro-area average, thanks to the strength of domestic demand-buoyed by private consumption and construction-while net exports have exercised a strong drag on economic growth. This pattern of growth has contributed to the maintenance of an inflation differential of about 1 percentage point vis-à-vis the euro area average. Concurrently, household indebtedness has continued rising amidst an ongoing real estate boom, with house prices experiencing double-digit increases for the sixth consecutive year. Despite a further erosion in competitiveness, overall export market shares have held up reasonably well, with, however, a continued compression of export margins. The external current account is estimated to have widened to some 41/4 percent of GDP in the first half of 2004.

A gradual, but sustained recovery is expected, with GDP growth projected at 2.7 percent in 2005-again based on the strength of domestic demand, with a continued negative contribution of net exports. Growth would thus continue to outstrip that expected for the euro area, but inflation is also projected to remain comparatively higher.

\footnotetext{
${ }^{1}$ Under Article IV of the IMF's Articles of Agreement, the IMF holds bilateral discussions with members, usually every year. A staff team visits the country, collects economic and financial information, and discusses with officials the country's economic developments and policies. On return to headquarters, the staff prepares a report, which forms the basis for discussion by the Executive Board. At the conclusion of the discussion, the Managing Director, as Chairman of the Board, summarizes the views of Executive Directors, and this summary is transmitted to the country's authorities.
} 
Policy conditions have been accommodative. In particular, real short-term interest rates have been negative for three years, spurring strong credit demand. The general government is estimated-excluding one-time adjustments-to have recorded a slight surplus in 2004, implying a mildly stimulatory stance. For 2005, the budget target of a 0.1 percent of GDP general government surplus implies a slightly restrictive fiscal stance. The authorities intend to modify the fiscal framework embodied in the Budgetary Stability Law to provide explicit scope for cyclical swings and increase observance by subnational governments in a highly devolved system.

The banking sector has maintained a strong financial position, helped by the favorable macroeconomic environment, the rebound of economic activity in Latin America, and vigilant prudential oversight. Rapidly rising real estate lending has heightened credit risk, but stress tests remain reassuring. A Financial Sector Assessment Program (FSAP) is scheduled for 2005.

On the structural front, earlier reforms in labor and product markets have improved the flexibility of these markets. Some long-standing issues remain however to be addressed, including notably pension reform, the wage negotiating framework, the land supply process, and competition in retail distribution.

\section{Executive Board Assessment}

They commended the authorities' skillful macroeconomic management and welcomed the economy's remarkably strong performance, reflected in the continued rapid rise in per capita incomes, vigorous job creation, and comparatively strong fiscal position. Sound policies-stemming from a well-established recognition of the benefits of fiscal discipline, wage moderation, and growth-enhancing structural reforms-underpin this performance. Directors endorsed the government's announced priorities of fiscal stability, transparency, and productivity enhancement, and welcomed the initiatives being taken in each of these areas. They looked forward to the further definition of policies in the period ahead to deal with both immediate and longer-term challenges and risks.

While short-term prospects remain favorable, Directors stressed that maintaining this positive outlook will require countering key domestic risks posed by the persisting real estate boom, rising household indebtedness, and an appreciable inflation differential with the euro area. While Directors recognized that the rise in house prices is partly driven by a number of fundamental factors, they cautioned that the longer the process continues, the greater the potential for an overshooting and an adverse fallout. At the same time, the unbalanced nature of the consumption-led growth, the prevalence of backward-looking wage indexation clauses, and the lack of sufficient competition in sheltered sectors risk prolonging inflation and further eroding competitiveness.

In the face of these risks, and given the presence of very accommodative monetary conditions for Spain, Directors stressed the importance of firm fiscal restraint. They thus welcomed the indications of a better-than-expected fiscal outcome in 2004 , boosted by the strength of tax revenues and social security contributions. Directors encouraged the authorities to build on this result and pursue a better-than-budgeted surplus in 2005 , 
by proactively containing central government spending below the budget ceiling, safeguarding the contingency fund, and fully saving the expected social security surplus. Directors also stressed the importance that regional governments-which account for a large share of expenditure-adhere firmly to their commitments to balanced budgets. While acknowledging the importance of prudent fiscal policy, some Directors noted that structural policies would be more effective in stemming inflationary pressures, given the underlying rigidities of the economy. In this connection, Directors supported the authorities' efforts to shift the composition of spending in favor of research, development, and education in order to enhance Spain's productivity and competitiveness over the medium term.

Directors highlighted the importance of a strong budgetary framework for the maintenance of Spain's hard-earned fiscal stability. They stressed that the primary objective of changes to the Budgetary Stability Law thus needed to be the promotion of greater overall fiscal discipline, with reliance on well-defined and transparent rules covering the desirable medium-term target, the methodology used to determine observance over the cycle, and the fiscal relations with subnational governments.

Directors stressed the importance of fiscal discipline at lower levels of government in Spain's highly decentralized system. In the absence of hard enforcement mechanisms for subnational governments, all available means to contain risks of fiscal laxity would need to be drawn upon. Many Directors advised that the regions should consistently aim at budget balance, avoiding a build-up in subnational debt. Directors felt that the regions could usefully adopt budgetary instruments that have proved effective at the central government level, such as an expenditure ceiling and a contingency fund. They also saw a role for increased regional revenue-raising powers and the establishment of independent agencies to assess budgetary developments and trends.

Directors noted that fiscal discipline would ultimately need to rely largely on dissuasive peer and public pressure, whose exercise requires the highest degree of fiscal transparency. They welcomed the positive assessment of the fiscal Report on the Observance of Standards and Codes (ROSC) that Spain meets, or exceeds, the Fiscal Transparency Code's standards in many areas, as well as the authorities' more recent steps to enhance transparency. However, Directors called for a significant improvement in the timeliness and publication of subnational budgetary data. Several Directors noted that such improved fiscal transparency would need to be an integral part of any changes to the Budgetary Stability Law.

Directors urged the authorities to assign higher priority to comprehensive pension reform, noting the slow progress under the Pacto de Toledo process to date. They remarked that the fiscal costs of aging, while arising comparatively later in Spain than in other EU countries, would still be considerable. While the build-up of the pension reserve fund is thus welcome, Directors stressed that such pre-funding could not by itself ensure the longer-run sustainability of social security. Reforms aimed at raising the effective retirement age and strengthening the link between contributions and benefits would also be needed. Directors noted that, if decided promptly, reform measures could be phased in gradually, avoiding the need for more difficult measures as the demographic shock nears. 
In the labor market, Directors welcomed the appreciable progress in key employment and other indicators, on the heels of a series of labor market reforms. Nonetheless, Spain continues to lag significantly behind key Lisbon objectives, and Directors encouraged the authorities to take further action to narrow this gap. The ongoing social dialogue should clearly aim to promote the labor market flexibility required for the smooth absorption of Spain's large immigration flows. In this vein, Directors suggested that reducing the rigidity and costs of standard open-ended contracts is the best way to reduce the uncommonly high rate of fixed-term contracts. They also reiterated the need to reform the collective wage bargaining system to assign greater attention to relative productivity developments, and move away from indexation clauses.

In goods and services markets, Directors supported the authorities' emphasis on increased competition in various areas, including through a modernization of the Competition Law. Directors expressed concern about the continued impediments to competition in retail trade and distribution enacted by subnational authorities. Noting that such barriers have costs for the regions themselves, they urged the authorities to continue working with subnational governments on policies to make competition effective throughout Spain. Finally, Directors noted the urgent need to address fundamental problems affecting the housing market, in particular by phasing out the generous tax relief favoring home ownership, changing the legal framework that discourages rental activity, and reforming the regulations constraining the supply of developable land.

Directors welcomed the further strengthening of the banking system, boosted by the favorable economic environment and the rebound of economic activity in Latin America. They noted, however, that the continued expansion of real estate-related lending has raised vulnerabilities, and welcomed the Bank of Spain's continued vigilance and the planned conduct of a Financial Sector Assessment Program. Directors also commended Spain's commitment to counter money laundering and the financing of terrorism.

Directors encouraged the authorities to build upon the increase in Spain's official development assistance in 2004, and to progress further toward the U.N. target. In noting Spain's support for trade liberalization, Directors urged the authorities to actively promote the completion of the Doha round, inter alia by supporting the flexibility needed on agricultural issues. Directors welcomed Spain's progress in increasing energy efficiency.

Public Information Notices (PINs) form part of the IMF's efforts to promote transparency of the IMF's views and analysis of economic developments and policies. With the consent of the country (or countries) concerned, PINs are issued after Executive Board discussions of Article IV consultations with member countries, of its surveillance of developments at the regional level, of post-program monitoring, and of ex post assessments of member countries with longer-term program engagements. PINs are also issued after Executive Board discussions of general policy matters, unless otherwise decided by the Executive Board in a particular case. 
Spain: Selected Economic Indicators, 2000-2005 1/

\begin{tabular}{|c|c|c|c|c|c|c|}
\hline & 2000 & 2001 & 2002 & 2003 & 2004 & 2005 \\
\hline \multicolumn{7}{|l|}{ Real economy (change in percent) } \\
\hline Real GDP & 4.4 & 2.8 & 2.2 & 2.5 & 2.6 & 2.7 \\
\hline Domestic demand & 4.6 & 2.9 & 2.8 & 3.2 & 3.9 & 3.9 \\
\hline HICP (average) & 3.5 & 2.8 & 3.6 & 3.1 & 3.0 & 3.5 \\
\hline Unemployment rate (in percent) & 13.9 & 10.5 & 11.4 & 11.3 & 10.8 & 10.4 \\
\hline \multicolumn{7}{|c|}{ Public finances (general government; in percent of GDP) 2/ } \\
\hline Overall balance & -0.8 & -0.3 & 0.1 & 0.4 & -0.8 & 0.3 \\
\hline Primary balance & 2.3 & 2.6 & 2.6 & 2.7 & 1.3 & 2.3 \\
\hline \multicolumn{7}{|l|}{ Interest rates } \\
\hline Money market rate & 4.4 & 4.3 & 3.3 & 2.3 & 2.1 & $\ldots$ \\
\hline Government bond yield & 5.5 & 5.1 & 5.0 & 4.1 & 4.4 & $\ldots$ \\
\hline \multicolumn{7}{|l|}{ Balance of payments (in percent of GDP) } \\
\hline Trade balance & -6.2 & -5.6 & -5.0 & -5.1 & -6.1 & 6.8 \\
\hline Current account & -3.4 & -2.8 & -2.4 & -2.8 & -4.0 & 4.6 \\
\hline \multicolumn{7}{|l|}{ Fund position (as of December 31, 2004) } \\
\hline Holdings of currency (in percent of quota) & & & & & 66.73 & \\
\hline Holdings of SDRs (in percent of allocation) & & & & & 71.61 & \\
\hline Quota (in millions of SDR) & & & & & $3,048.90$ & \\
\hline \multicolumn{7}{|l|}{ Exchange rate } \\
\hline Exchange rate regime & \multicolumn{6}{|c|}{ Euro Area Member } \\
\hline Present rate (January 18,2005 ) & \multicolumn{6}{|c|}{ US\$ 1.3060 per euro } \\
\hline Nominal effective exchange rate $(1990=100)$ & 71.9 & 72.3 & 74.2 & 75.9 & & \\
\hline Real effective exchange rate $(1990=100)$ & 82.1 & 83.6 & 87.6 & 89.9 & & \\
\hline
\end{tabular}

Sources: IMF, World Economic Outlook, Information Notice System; and IMF staff estimates.

1/ Figures for 2003-2004 are Fund staff projections.

2/ Maastricht basis. 